\title{
Synthesis and Ligand Substitution Reactions of $\kappa^{4}-B, S, S^{\prime}, S^{\prime \prime}-$ Ruthenaboratranes
}

A range of ruthenaboratranes of the form $\left[R u(C O) L\left\{\kappa^{4}-B, S, S^{\prime}, S^{\prime \prime}-B(m t)_{3}\right\}\right](m t=N$-methylmercaptoimidazolyl) have been prepared either by substitution of the $\mathrm{PPh}_{3}$ ligand in $\left[R u(C O)\left(\mathrm{PPh}_{3}\right)\left\{\kappa^{4}-B, S, S^{\prime}, S^{\prime \prime}-\mathrm{B}(\mathrm{mt})_{3}\right\}\right]$ by $L\left(L=P M e_{2} P h, P M e_{3}, P(O M e)_{3}\right.$, $\left.\mathrm{P}(\mathrm{OEt})_{3}, \mathrm{P}(\mathrm{OPh})_{3}\right)$ or reactions of $\left[\mathrm{RuCl}(\mathrm{R})(\mathrm{CO}) \mathrm{L}_{n}\right]\left(\mathrm{R}=\mathrm{Ph}, \mathrm{CH}=\mathrm{CHPh} ; \mathrm{n}=2 \mathrm{~L}=\mathrm{PCy} ; \mathrm{n}=3 \mathrm{~L}=\mathrm{P}(\mathrm{OMe})_{3}, \mathrm{PMe} \mathrm{e}_{2} \mathrm{Ph}\right)$ with $\mathrm{Na}\left[\mathrm{HB}(\mathrm{mt})_{3}\right]$.

\section{Introduction}

Metallaboratranes ${ }^{1}$ are cage structures in which a transannular dative (polar covalent, ${ }^{2} \mathrm{M} \rightarrow \mathrm{B}$ ) bond between a transition metal and boron is supported by two or three buttressing bridges (Chart 1). Metallaboratranes with $N$-heterocyclic buttresses are known for all the elements of groups $8,{ }^{3,49} 9,{ }^{4} 10^{5}$ and 11,6 with the majority of studies involving the heavier elements of group 9. ${ }^{4}$ In contrast, despite the archetype $\left[\mathrm{Ru}(\mathrm{CO})\left(\mathrm{PPh}_{3}\right)\left\{\kappa^{4}-\right.\right.$ $\left.B, S, S^{\prime}, S^{\prime \prime}-B(m t)_{3}\right]$ (1a mt $=N$-methyl-2-mercaptoimidazolyl), ${ }^{3 b, 7}$ being based on ruthenium, very few further examples have been described within group 8 , these being limited to Parkin's ferraboratrane $\left[\mathrm{Fe}(\mathrm{CO})_{2}\left\{\mathrm{~B}\left(\mathrm{mt}^{\mathrm{tBu}}\right)_{3}\right\}\right]$, ${ }^{3 a}$ the osmaboratrane analogue of $1 a^{3 f}$ the ruthenaboratranes $\left[R u(C S)\left(\mathrm{PPh}_{3}\right)\left\{\kappa^{4}-\right.\right.$ $\left.B, S, S^{\prime}, S^{\prime \prime}-B(m t)_{3}\right](2)$ and $\left[R u(C O)(C N R)\left\{B(m t)_{3}\right]\left(R={ }^{t} B u \quad 1 c\right.\right.$, $\mathrm{C}_{6} \mathrm{H}_{3} \mathrm{Me}_{2}-2,6$ 1d, $\mathrm{C}_{6} \mathrm{H}_{2} \mathrm{Me}_{3}-2,4,6$ 1e), ${ }^{4 c}$ and the $N$-chlorophenyl analogue of $1 a^{4 d}$

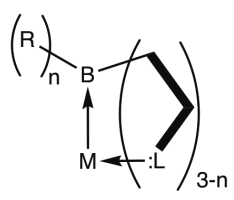

Metallaboratrane $(\mathrm{n}=0,1 ; \mathrm{R}=\mathrm{H}, \mathrm{Ph})$

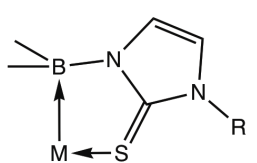

$N$-R-mercaptoimidazolylmetallaboratranes

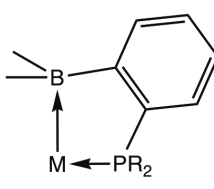

2-Phosphinoarylmetallaboratranes

Chart 1. The metallaboratrane motif.

The poly(2-phosphinophenyl)borane scaffold pioneered by Bourissou ${ }^{8}$ has been applied to metals from groups $9,8,910^{10}$ and $11^{11}$ but it is with iron, as developed by Peters, ${ }^{12}$ that the ligand system has enjoyed the most intense study, rewarded

a. Department of Chemistry and Chemical Engineering, Nuclear Chemistry and Industrial Materials Recycling, Chalmers University of Technology, Göteborg, Sweden.

${ }^{b}$ Research School of Chemistry, Australian National University, Acton, Canberra, A.C.T., Australia.

c. Department of Chemistry, University of Botswana, Gaborone, Botswana.

d. Chemical Crystallography Laboratory, Department of Chemistry, Imperial College London White City Campus, United Kingdom, W12 0BZ.

$\dagger$ Electronic Supplementary Information (ESI) available: Crystallographic information files CCDC 1874175 - 1874179 relate to compounds discussed herein. with impressive results in supporting inter alia the stoichiometric reduction of $\mathrm{CO}$ and the catalytic reduction of $\mathrm{N}_{2}$.

This dearth of group 8 metallaboratranes is perhaps counter-intuitive in that of all the late transition metals, those of group 8 in the formally zerovalent state ${ }^{13}$ are likely to be the strongest $\sigma$-bases and best able to stabilise the Lewis acidic boron through Z-type polar-covalent bonding. ${ }^{14}$ We therefore contend that the scarcity of group $8 \quad(M \rightarrow B)^{8}$ metallaboratranes ${ }^{15}$ is an historical oversight rather than any reflection on their stability or accessibility. Accordingly, we describe herein the synthesis of a range of new ruthenaboratranes for the purpose of assessing the varying impact of co-ligands upon the $(R u \rightarrow B)^{8}$ dative interaction.

\section{Results and Discussion}

The first metallaboratrane, 1a, arose from the unexpected reaction of $\left[\mathrm{RuCl}(\mathrm{R})(\mathrm{CO})\left(\mathrm{PPh}_{3}\right)_{2}\right](\mathrm{R}=\mathrm{Ph}, \mathrm{CH}=\mathrm{CHPh})$ with $\mathrm{Na}\left[\mathrm{HB}(\mathrm{mt})_{3}\right]$ via activation of the borohydride group and elimination of benzene or styrene. ${ }^{3 b, c}$ The $\mathrm{B}-\mathrm{H}$ activation step is presumed to proceed via coordination of this group to the ruthenium centre via a 3 centre 2-electron $\mathrm{B}-\mathrm{H} \cdots \mathrm{Ru}$ association, isolable related examples of which include the complexes $\left[\mathrm{RuH}(\mathrm{CO})\left(\mathrm{PPh}_{3}\right)\left\{\kappa^{3}-H, S, S^{\prime}-\mathrm{HB}(\mathrm{mt})_{3}\right\}\right]^{3 \mathrm{~d}} \quad\left[\mathrm{RuH}\left(\mathrm{PPh}_{3}\right)_{2}\left\{\kappa^{3}-H, S, S^{\prime}-\right.\right.$ $\left.\left.\mathrm{H}_{2} \mathrm{~B}(\mathrm{mt})_{2}\right\}\right]^{16 a}$ and $\left[\mathrm{RuX}(\mathrm{CO})\left(\mathrm{PPh}_{3}\right)\left\{\kappa^{3}-\mathrm{H}, \mathrm{S}, \mathrm{S}^{\prime}-\mathrm{H}_{2} \mathrm{~B}(\mathrm{mt})_{2}\right\}\right](\mathrm{X}=\mathrm{H}, \mathrm{Cl}$, $\left.\mathrm{SePh}, \mathrm{SiCl}_{3}, \mathrm{SiMe}_{3}, \mathrm{BO}_{2} \mathrm{C}_{6} \mathrm{H}_{4}\right) .{ }^{16 \mathrm{~b}}$ The factors that dictate why in some but by no means all cases this coordination mode proceeds to $\mathrm{B}-\mathrm{H}$ activation and metallaboratane formation are not well delineated, though the reverse process, i.e., migration of a hydride ligand to a cis $\mathrm{M} \rightarrow \mathrm{B}$ bond has been observed on rare occasions for platina-, $5 c, \mathrm{i}$ rhoda- $4 \mathrm{r}, 9 \mathrm{e}$ and ferraboratranes. ${ }^{12}$ It may well be therefore that this process does indeed surreptitiously operate more widely and reversibly but not to spectroscopically determinable extents.

Perhaps surprisingly, the phosphine ligand in 1a was shown to be labile under mild conditions, being reversibly displaced by $\mathrm{CO}$ to provide $\left[\mathrm{Ru}(\mathrm{CO})_{2}\left\{\kappa^{4}-B, S, S^{\prime}, S^{\prime \prime}-\mathrm{B}(\mathrm{mt})_{3}\right]\right.$ (1b) which however reverted to 1a under vacuum. Irreversible substitution however ensued with isonitriles to provide a $\left[R u(C O)(L)\left\{\kappa^{4}-B, S, S^{\prime}, S^{\prime \prime}\right.\right.$ $\left.\left.\mathrm{B}(\mathrm{mt})_{3}\right\}\right]\left(\mathrm{L}=\mathrm{CN}^{t} \mathrm{Bu}\right.$ 1c, $\mathrm{CNC}_{6} \mathrm{H}_{3} \mathrm{Me}_{2}-2,6$ 1d, $\mathrm{CNC}_{6} \mathrm{H}_{2} \mathrm{Me}_{3}-2,4,6$ 1e). ${ }^{3 c}$ The syntheses of new ruthenaboratranes to be described 
herein therefore take one of two different approaches; either (i) ligand substitution reactions of 1a with a range of phosphines or (ii) pre-installation of the phosphine prior to ruthenaboratrane assembly.

Treating a solution of $1 \mathrm{a}$ with a slight excess of $\mathrm{PMe}_{2} \mathrm{Ph}$ in dichloromethane at room temperature results in complete phosphine substitution with the formation of $\left[\mathrm{Ru}(\mathrm{CO})\left(\mathrm{PMe}{ }_{2} \mathrm{Ph}\right)\left\{\kappa^{4}-B, S_{,} S^{\prime}, S^{\prime \prime}-\mathrm{B}(\mathrm{mt})_{3}\right\}\right]$ (1f, Scheme 1).

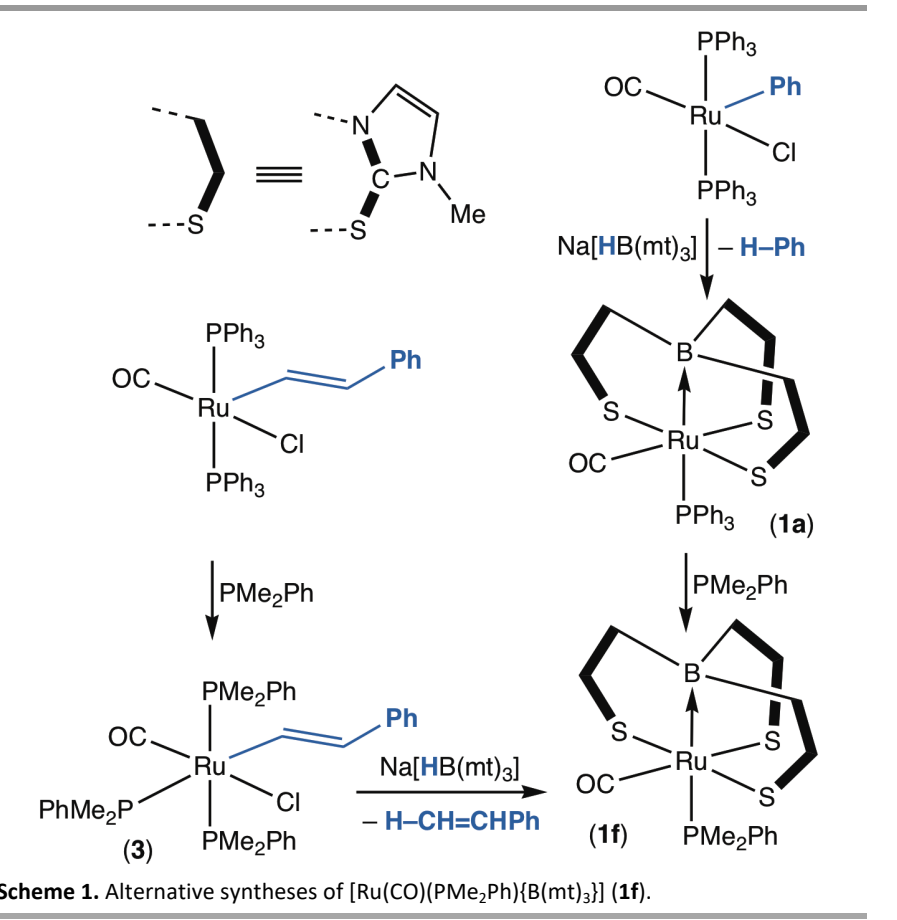

Alternatively, $\mathbf{1 f}$ may be prepared by installing $\mathrm{PMe}_{2} \mathrm{Ph}$ prior to the ruthenaboratrane assembly. Mawby has described the synthesis of $\operatorname{mer}-\left[\mathrm{RuCl}(\mathrm{Ph})(\mathrm{CO})\left(\mathrm{PMe}_{2} \mathrm{Ph}\right)_{3}\right]$ via the reaction of $\left[\mathrm{RuCl}(\mathrm{Ph})(\mathrm{CO})\left(\mathrm{PPh}_{3}\right)_{2}\right]$ with excess $\mathrm{PMe}_{2} \mathrm{Ph}^{17}$ and a similar protocol converts $\left[\mathrm{RuCl}(\mathrm{CH}=\mathrm{CHPh})(\mathrm{CO})\left(\mathrm{PPh}_{3}\right)_{2}\right]^{18}$ to mer$\left[\mathrm{RuCl}(\mathrm{CH}=\mathrm{CHPh})(\mathrm{CO})\left(\mathrm{PMe}_{2} \mathrm{Ph}\right)_{3}\right] \mathbf{3}$ in $79 \%$ yield (Scheme 1$)$. The characterisation of $\mathbf{3}$ included a crystallographic analysis (Figure 1) and is generally unremarkable other than to note that (i) the mer-RuP $\mathrm{P}_{3}$ geometry is confirmed both crystallographically and from ${ }^{31} \mathrm{P}\left\{{ }^{1} \mathrm{H}\right\} \mathrm{NMR}$ data $\left(\mathrm{CDCl}_{3}: \delta_{\mathrm{p}}=-8.80 \mathrm{t},-1.17 \mathrm{dt},{ }^{2} \mathrm{PP}=23.1\right.$ $\mathrm{Hz}$ ) and (ii) The $\sigma$-styryl ligand, as expected for a $\sigma$-organyl, exerts a discernible trans influence upon the unique phosphine (Ru1-P2 = 2.4148(9) $\AA$ ) relative to the mutually trans disposed pair of phosphines, however the significant disparity between these two Ru-P bonds (Ru1-P1 = 2.3573(9), Ru1-P3 = 2.3971(9) $\AA)$ is itself noteworthy given their spectroscopic chemical equivalence. A search for inter- or intramolecular close-contacts failed to identify any interactions that might be responsible, leading us to conclude that this is simply a response to

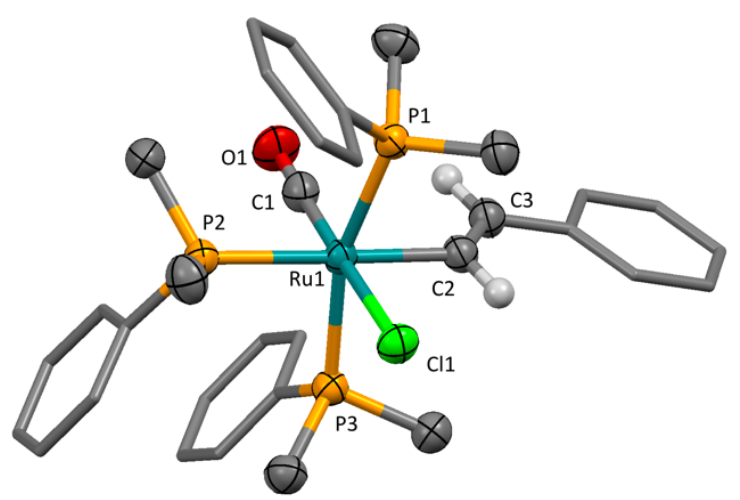

Figure 1. Molecular structure of $\mathbf{3}$ (Most hydrogen atoms omitted, phenyl groups simplified, 50\% displacement ellipsoids). Selected bond lengths $(\AA)$ and angles $\left({ }^{\circ}\right)$ : Ru1Cl1 2.4815(8), Ru1-P1 2.3573(9), Ru1-P2 2.4148(9), Ru1-P3 2.3971(9), Ru1-C1 1.818(4), Ru1-C2 2.106(3), C2-C3 1.329(5), C3-C4 1.483(5), Cl1-Ru1-P1 86.33(3), Cl1-Ru1-P2 93.18(3), P1-Ru1-P2 97.53(3), Cl1-Ru1-P3 83.66(3), P1-Ru1-P3 163.10(3), P2-Ru1-P3 96.59(3), P1-Ru1-C1 92.59(12), P2-Ru1-C1 87.82(11), P3-Ru1-C1 97.18(12), Cl1-Ru1C2 88.6(1), P1-Ru1-C2 82.4(1), P3-Ru1-C2 83.73(9), C1-Ru1-C2 90.44(15), Ru1-C2-C3 130.1(3), C2-C3-C4 126.9(3).

meridionally accommodating the three irregularly shaped phosphines.

Heating 3 with $\mathrm{Na}\left[\mathrm{HB}(\mathrm{mt})_{3}\right]$ in THF under reflux for 12 hours returns $1 \mathrm{f}$ in $51 \%$ yield. The phosphine associated resonance which appear at $\delta_{\mathrm{P}}=-13.3\left(\mathrm{CDCl}_{3}\right)$ in the ${ }^{31} \mathrm{P}\left\{{ }^{1} \mathrm{H}\right\}$ NMR spectrum of $1 \mathrm{f}$ is conspicuously broad consistent with coordination trans to the quadrupolar boron of the metallaboratrane. The ${ }^{11} \mathrm{~B}\left\{{ }^{1} \mathrm{H}\right\}$ NMR spectrum comprises an apparent singlet resonance $\left(\mathrm{CDCl}_{3}\right.$ : $\left.\delta_{\mathrm{B}}=15.4\right)$, the broadness of which precluded the resolution of $2 J_{\mathrm{PB}}$. The molecular geometry of $\mathbf{1 f}$ is depicted in Figure 2 and geometric features will be discussed collectively alongside other examples to follow.

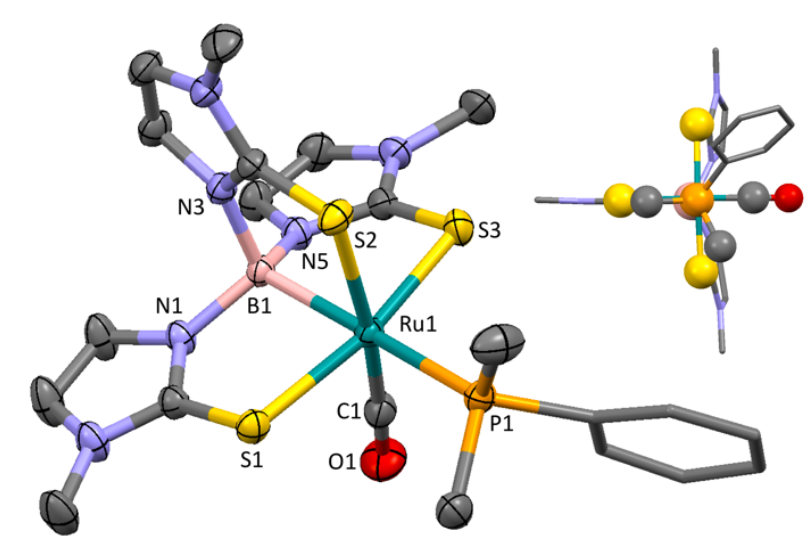

Figure 2. Molecular structure of $\mathbf{1 f}$ (Hydrogen atoms omitted, phenyl and methimazolyl groups simplified, $50 \%$ displacement ellipsoids). Inset = view along Ru1 $\cdots$ P1 vector. Selected bond lengths $(\AA)$ and angles $\left({ }^{\circ}\right)$ : B1-Ru1 2.174(3), B1-N1 1.561(4), B1-N3 1.580(4), B1-N5 1.561(4), Ru1-S1 2.3881(7), Ru1-S2 2.4938(7), Ru1-S3 2.4071(8), Ru1P1 2.4170(7), Ru1-B1-N1 110.41(18), Ru1-B1-N3 110.57(18), N1-B1-N3 105.7(2), Ru1B1-N5 109.74(18), N1-B1-N5 114.5(2), N3-B1-N5 105.7(2) B1-Ru1-S1 83.44(8), B1Ru1-S2 85.21(8), S1-Ru1-S2 90.92(3), B1-Ru1-S3 82.84(8).

Whilst the replacement of $\mathrm{PPh}_{3}$ in $\mathbf{1 a}$ by the more compact and strongly $\sigma$-basic phosphine $\mathrm{PMe}_{2} \mathrm{Ph}$ proceeded quickly under mild conditions, the same reaction involving the more sterically demanding phosphine $\mathrm{PC}_{3}$ did not proceed to 
completion but rather afforded an equilibrium mixture of 1a and $\left[\mathrm{Ru}(\mathrm{CO})\left(\mathrm{PCy}_{3}\right)\left\{\kappa^{4}-B, S, S^{\prime}, S^{\prime \prime}-\mathrm{B}(\mathrm{mt})_{3}\right\}\right]$ (1g, Scheme 2).

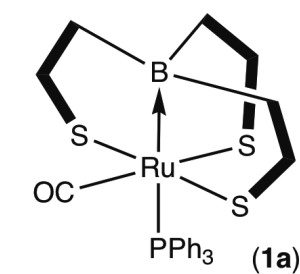

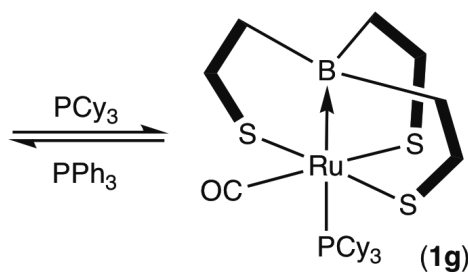

(1a)<smiles>CC[Al](C)C(C)C</smiles><smiles></smiles>

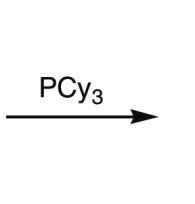

Scheme 2. Alternative syntheses of $\left[\mathrm{Ru}(\mathrm{CO})\left(\mathrm{PCy}_{3}\right)\left\{\mathrm{B}(\mathrm{mt})_{3}\right\}\right](\mathbf{1 g})$.

This mixture proved too problematic to separate and accordingly the alternative pre-installation approach was found to be preferable. Aerobic decomposition of Grubbs' catalyst $\left[\mathrm{RuCl}_{2}(=\mathrm{CHPh})\left(\mathrm{PCy}_{3}\right)_{2}\right]$ has been shown to provide $\left[\mathrm{RuCl}(\mathrm{Ph})(\mathrm{CO})\left(\mathrm{PCy}_{3}\right)_{2}\right](4),{ }^{19}$ but in the present work 4 was more conveniently obtained in $80 \%$ yield simply by heating $\left[\mathrm{RuCl}(\mathrm{Ph})(\mathrm{CO})\left(\mathrm{PPh}_{3}\right)_{2}\right]$ with excess $\mathrm{PCy}_{3}$. The reaction of 4 with $\mathrm{Na}\left[\mathrm{HB}(\mathrm{mt})_{3}\right]$ in dichloromethane proceeds to completion within 2 hours to cleanly provide $\mathbf{1 g}$ in $77 \%$ yield, obviating the $\mathrm{PPh}_{3}$ and 1a contamination problems encountered in the initial route. The molecular structure of $\mathbf{1 g}$ is shown in Figure 3 , from which the steric bulk of the $\mathrm{PC}_{3}$ ligand is immediately obvious relative to that of the phosphines in $\mathbf{1 a}$ and $\mathbf{1} \mathbf{f}$ (vide infra, Figure 7).

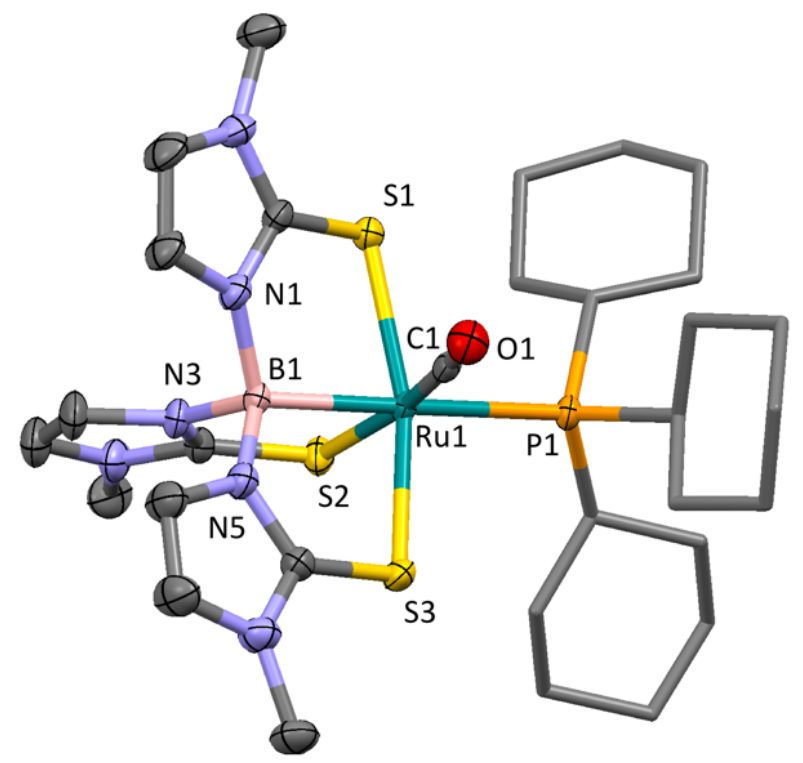

Figure 3. Molecular structure of $1 \mathrm{~g}$ in a crystal of $1 \mathrm{~g} \cdot \mathrm{CH}_{2} \mathrm{Cl}_{2}$ (Hydrogen atoms and solvent omitted, cyclohexyl and methimazolyl groups simplified, 50\% displacement ellipsoids). Selected bond lengths $(\AA)$ and angles $\left({ }^{\circ}\right)$ : B1-Ru1 2.168(3), B1-N1 1.568(4), B1-N3 1.568(4), B1-N5 1.560(5), Ru1-S1 2.4188(8), Ru1-S2 2.4922(8), Ru1-S3 2.4084(8), Ru1P1 2.4894(7), Ru1-B1-N1 110.4(2), Ru1-B1-N3 110.2(2), N1-B1-N3 105.6(2), Ru1-B1N5 111.2(2), N1-B1-N5 112.6(3), N3-B1-N5 106.6(3), B1-Ru1-S1 81.45(10), B1-Ru1-S2
85.49(10), S1-Ru1-S2 89.83(3), B1-Ru1-S3 83.36(10), S1-Ru1-S3 164.73(3), S2-Ru1-S3 $90.59(3)$.

In contrast to the steric encumbrance and high $\sigma$-basicity of the $\mathrm{PCy}_{3}$ ligand in $\mathbf{1} \mathbf{g}$, the more compact derivative $\left[\mathrm{Ru}(\mathrm{CO})\left(\mathrm{PMe}_{3}\right)\left\{\mathrm{B}(\mathrm{mt})_{3}\right\}\right] \quad(\mathbf{1 h})$ was obtained via simple substitution of $\mathrm{PPh}_{3}$ in $1 \mathrm{a}$ by $\mathrm{PMe}_{3}$. The molecular geometry of $\mathbf{1 h}$ is shown in Figure 4 and data are discussed collectively below. Notably, in contrast to the reversible reaction of $\mathbf{1 a}$ with $\mathrm{CO}$ to provide $\mathbf{1 b}$ and its irreversible reaction with $\mathrm{CN}^{t} \mathrm{Bu}$, to afford $\mathbf{1 c}$, the $\mathrm{PMe}_{3}$ ligand in $\mathbf{1 h}$ is displaced by neither $\mathrm{CO}$ nor $\mathrm{CN}^{t} \mathrm{Bu}$ under ambient conditions $\left(\mathrm{CH}_{2} \mathrm{Cl}_{2}, 12 \mathrm{hrs}\right)$.

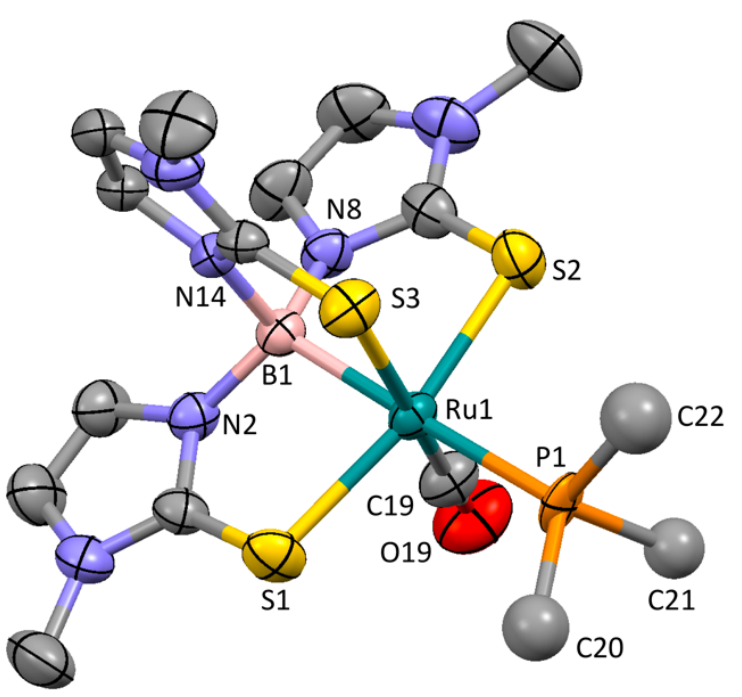

Figure 4. Molecular structure of $\mathbf{1 h}$ in a crystal (Hydrogen atoms and solvent omitted, , $50 \%$ displacement ellipsoids). Selected bond lengths ( $(\AA)$ and angles ( $\left(^{\circ}\right)$ : Ru1-B1 2.157(6), Ru1-S2 2.3929(17), Ru1-S1 2.4068(17), Ru1-P1 2.423(7), Ru1-S3 2.5103(15), B1-N2 1.558(7), B1-N8 1.559(8), B1-N14 1.587(8), B1-Ru1-S2 83.35(17), B1-Ru1-S1 82.90(17), B1-Ru1-S3 85.45(17), N2-B1-N8 114.0(4), N2-B1-N14 104.6(4), N8-B1-N14 105.3(4). The $\mathrm{PMe}_{3}$ ligand was disordered over three positions (ca 46, 32 and $22 \%$ occupancy) with the major occupancy isotropically refined components shown.

Of the three phosphines in $\mathbf{1 a}, \mathbf{1 f}, \mathbf{1 g}$ and $\mathbf{1 h}, \mathrm{PCy}_{3}$ has the lowest Tolman electronic parameter ${ }^{20}$ which is also reflected in $1 \mathrm{~g}$ having the lowest $v_{\mathrm{CO}}$ value $\left(\mathrm{CH}_{2} \mathrm{Cl}_{2}: 1876 \mathrm{~cm}^{-1}\right)$, well within the region typical of zerovalent ruthenium complexes. Having prepared two ruthenaboratranes with strongly $\sigma$-basic phosphines with small $\left(\mathrm{PMe}_{3}, \theta_{\mathrm{T}}=118^{\circ}\right)$ and large $\left(\mathrm{PCy}_{3}: \theta_{\mathrm{T}}=\right.$ $170^{\circ}$ ) Tolman cone angles ${ }^{20}$ we next turned to phosphorus ligands with modest steric profiles but reduced donor strength, i.e., phosphites (Chart 2) to broaden the ligand space under consideration.

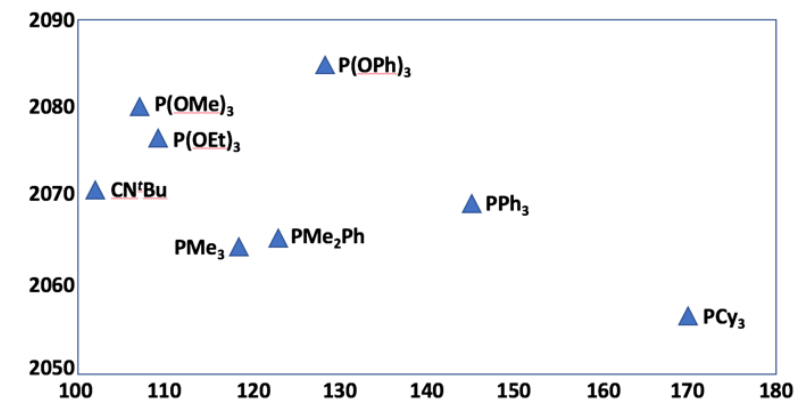


Chart 2. Distribution of Phosphines Employed Across Tolman Steric $\left(\boldsymbol{\theta}_{\mathrm{T}}\right)$ and Electronic $\left(\boldsymbol{v}_{\mathrm{T}}\right)$ Space

Both synthetic approaches described above proved successful, though in both cases more forcing conditions and extended reaction times were required to complete the conversions. Thus 1 a reacted with $\mathrm{P}(\mathrm{OMe})_{3}$ to provide modest yields of $\left[\mathrm{Ru}(\mathrm{CO})\left\{\mathrm{P}(\mathrm{OMe})_{3}\right\}\left\{\mathrm{B}(\mathrm{mt})_{3}\right\}\right](\mathbf{1 i}$, Scheme 3$)$ when heated for 16 hours in refluxing hexane $(59 \%)$ or THF $(49 \%)$.<smiles></smiles>

(6)<smiles>COP(C)(C)(C)C</smiles>

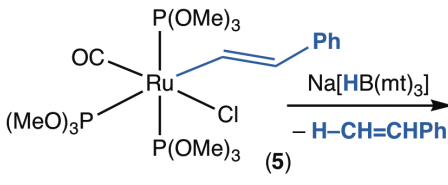
(5)

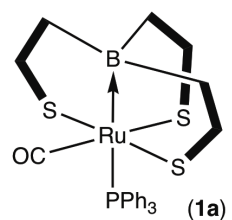

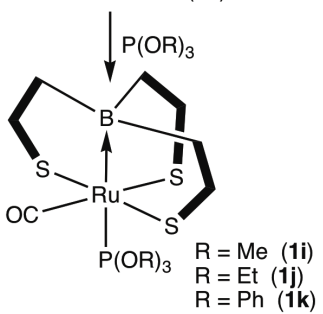

Scheme 3. Alternative syntheses of $\left[\mathrm{Ru}(\mathrm{CO})\left\{\mathrm{P}(\mathrm{OR})_{3}\right\}\left\{\mathrm{B}(\mathrm{mt})_{3}\right\}\right](\mathrm{R}=\mathrm{Me} \mathbf{1} \mathbf{i}$, Et $\mathbf{1 j}$, Ph $\mathbf{1 k})$

Similar results were obtained for the formation of triethyl (1j) and triphenyl (1k) analogues. Complex $\mathbf{1 i}$ failed to provide crystallographic grade crystals however both $\mathbf{1 j}$ (Figure 5) and $\mathbf{1 k}$ (Figure 6) were structurally characterised and their structural features are discussed below. Passing a stream of $\mathrm{CO}$ through a dichloromethane solution of $\mathbf{1 i}$ results in ca $30 \%$ conversion to $\left[\mathrm{Ru}(\mathrm{CO})_{2}\left\{\mathrm{~B}(\mathrm{mt})_{3}\right\}\right]$ (1b: 2020, $\left.1994 \mathrm{~cm}^{-1}\right)$ which was however cleanly converted back to $1 \mathbf{i}$ when the CO stream was replaced with a nitrogen purge, or the sample simply left to evaporate.

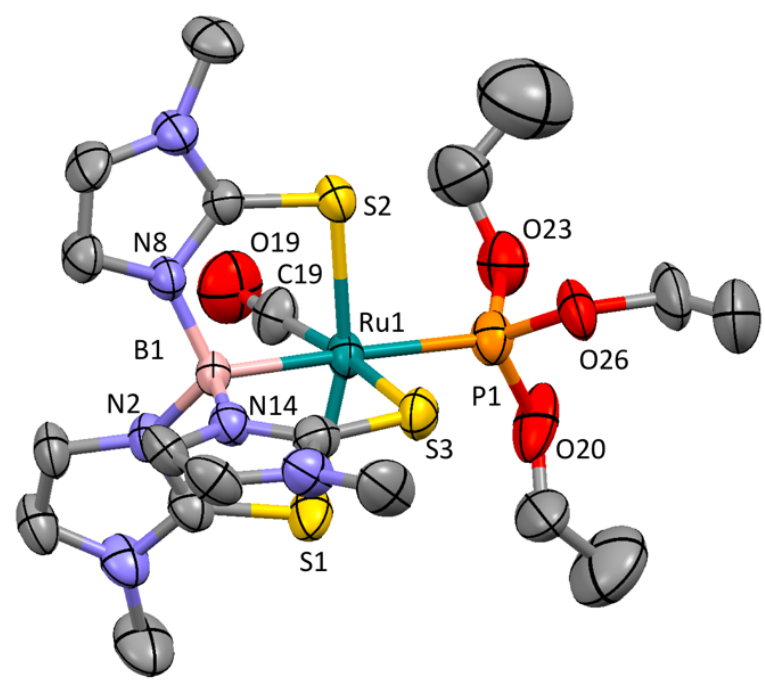

Figure 5. Molecular structure of $\mathbf{1 j}$ (Hydrogen atoms omitted, groups simplified, 50\% displacement ellipsoid). Selected bond lengths (Å) and angles ( ${ }^{\circ}$ ): Ru1-B1 2.172(6), Ru1 P1 2.360(6), Ru1-S2 2.4018(16), Ru1-S1 2.4306(19), Ru1-S3 2.4781(17), B1-N8 1.559(8), B1-N2 1.560(8), B1-N14 1.571(8), B1-Ru1-S2 83.45(18), B1-Ru1-S1 80.79(19), B1Ru1-S3 85.33(18), N8-B1-N2 112.6(5), N8-B1-N14 104.9(5), N2-B1-N14 107.8(5). Each OEt group suffers position disorder, with only the major occupancy components shown

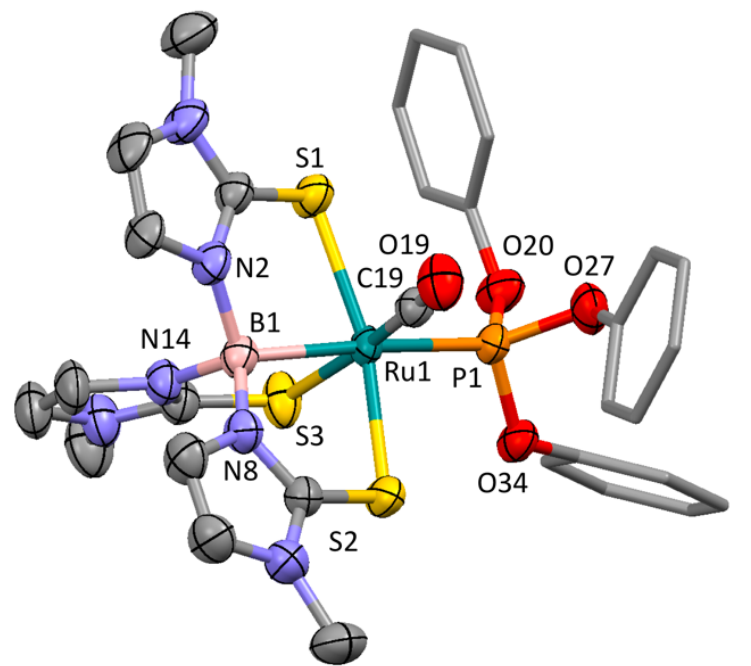

Figure 6. Molecular structure of $\mathbf{1 k}$ (Hydrogen atoms omitted, phenyl groups simplified, $50 \%$ displacement ellipsoids). Selected bond lengths $(\AA \AA)$ and angles $\left({ }^{\circ}\right)$ : Ru1-B1 2.184(6), Ru1-P1 2.314(4), Ru1-S2 2.4048(14), Ru1-S1 2.4167(13), Ru1-S3 2.4776(14), B1-N14 1.564(7), B1-N8 1.568(7), B1-N2 1.568(7), B1-Ru1-S2 82.88(15), B1-Ru1-S1 81.54(15), B1-Ru1-S3 85.02(15), N14-B1-N8 107.3(4), N14-B1-N2 104.8(4), N8-B1-N2 113.5(4). Each OPh group suffers position disorder, with only the major occupancy components shown.

Alternatively, mer- $\left[\mathrm{RuCl}(\mathrm{CH}=\mathrm{CHPh})(\mathrm{CO})\left\{\mathrm{P}(\mathrm{OMe})_{3}\right\}_{3}\right]$ (5) was prepared by heating $\left[\mathrm{RuCl}(\mathrm{CH}=\mathrm{CHPh})(\mathrm{CO})\left(\mathrm{PPh}_{3}\right)_{2}\right]^{18}$ with excess $\mathrm{P}(\mathrm{OMe})_{3}$ in hexane under reflux for 16 hours as described previously for the synthesis of $\left[\mathrm{RuCl}(\mathrm{Ph})(\mathrm{CO})\left\{\mathrm{P}(\mathrm{OMe})_{3}\right\}_{3}\right] .{ }^{17}$ Although the yield of this conversion was spectroscopically quantitative, the high solubility compromised the isolated yield (59\%). Reduced reaction times provide samples contaminated with mer-trans-[RuCl$\left.(\mathrm{CH}=\mathrm{CHPh})(\mathrm{CO})\left(\mathrm{PPh}_{3}\right)_{2}\left\{\mathrm{P}(\mathrm{OMe})_{3}\right\}\right]$ which could be acquired in pure form via reaction of $\left[\mathrm{RuCl}(\mathrm{CH}=\mathrm{CHPh})(\mathrm{CO})\left(\mathrm{PPh}_{3}\right)_{2}\right]$ with one equivalent of $\mathrm{P}(\mathrm{OMe})_{3}$ at room temperature. The mer-RuP $\mathrm{P}_{3}$ geometry of 5 was confirmed by ${ }^{31} \mathrm{P}\left\{{ }^{1} \mathrm{H}\right\}$ NMR spectroscopy $\left(\mathrm{AB}_{2}: \delta_{\mathrm{P}}=128.9 \mathrm{~d}, 142.4 \mathrm{t},{ }^{2} \mathrm{~J}_{\mathrm{AB}}=\right.$ $43.0 \mathrm{~Hz}$ ). Heating 6 with $\mathrm{Na}\left[\mathrm{HB}(\mathrm{mt})_{3}\right]$ in refluxing THF for 12 hours afforded $1 \mathbf{i}$ in $59 \%$ yield. As with the other derivatives, the resonance for the phosphite in the ${ }^{31} \mathrm{P}\left\{{ }^{1} \mathrm{H}\right\}$ NMR spectrum was broadened $\left(\delta_{\mathrm{P}}=159.1\right)$ indicating coupling between the ${ }^{31} \mathrm{P}$ and quadrupolar ${ }^{11} \mathrm{~B}$ nuclei, however the ${ }^{11} \mathrm{~B}$ resonance $\left(\delta_{\mathrm{B}}=15.4\right)$ was not much moved from those for derivatives with more $\sigma$ basic (less $\pi$-acidic) phosphines. These and other spectroscopic data are collated in Table 1.

Table 1. Tolman Steric $\left(\boldsymbol{\theta}_{\mathrm{T}}\right)$ and Electronic $\left(\boldsymbol{\nu}_{\mathrm{T}}\right)$ parameters for phosphines and selected structural data for ruthenaboratranes $\left[\mathrm{Ru}(\mathrm{CO})(\mathrm{L})\left\{\mathrm{B}(\mathrm{mt})_{3}\right\}\right](\mathbf{1})$

$\begin{array}{lllllll}\mathrm{L} & \boldsymbol{\theta}_{\mathrm{T}} & \boldsymbol{v}_{\mathrm{T}} & v_{\mathrm{CO}} & \delta_{\mathrm{B}} & r_{\text {RuB }} & r_{\text {RuP }} \\ \mathrm{PC}_{3} & 170 & 2056.4 & 1876 & 15.4 & 2.168(3) & 2.4894(7) \\ \mathrm{PPh}_{3} & 145 & 2068.9 & 1894 & 17.1 & 2.161(5) & 2.435(1) \\ \mathrm{P}(\mathrm{OPh})_{3} & 128 & 2085.3 & 1923 & 13.0 & 2.184(6) & 2.314(4) \\ \mathrm{PMe}_{2} \mathrm{Ph} & 122 & 2065.3 & 1887 & 15.4 & 2.174(3) & 2.4170(7) \\ \mathrm{PMe}_{3} & 118 & 2064.1 & 1885 & 14.6 & 2.157(6) & 2.423(7) \\ \mathrm{P}(\mathrm{OEt})_{3} & 108 & 2076.3 & 1904 & 14.0 & 2.172(6) & 2.360(6) \\ \mathrm{P}(\mathrm{OMe})_{3} & 107 & 2079.5 & 1907 & 14.5 & - & - \\ \mathrm{CN}^{t} \mathrm{Bu} & 102^{a} & 2071.3^{b} & 1894 & 14.6 & 2.176(7) & -\end{array}$

${ }^{a}$ Taken from reference $21 .{ }^{b}\left[\mathrm{Ni}\left(\mathrm{CN}^{t} \mathrm{Bu}\right)(\mathrm{CO})_{3}\right]$ has not been reported, the value given here is for $\left[\mathrm{Ni}\left(\mathrm{CN}^{n} \mathrm{Bu}\right)(\mathrm{CO})_{3}\right] .22$. 
The comparative $\pi$-acidity of the phosphite relative to phosphines is, however, indirectly manifested in the $v_{\text {co }}$ values $\left(\mathrm{CH}_{2} \mathrm{Cl}_{2}\right.$ : 1i 1907, 1k $\left.1923 \mathrm{~cm}^{-1}\right)$ being the highest for the series,. Taking the range of ruthenaboratranes together, Table 1 collates the two key structural features, i.e., the bond lengths between ruthenium and phosphorus or boron, contextualised by the Tolman steric and electronic parameters. ${ }^{20}$

Despite Tolman's electronic parameter being derived from the $A_{1}$ vibrational mode for $C_{3 v^{-}}\left[\mathrm{Ni}(\mathrm{CO})_{3}\left(\mathrm{PR}_{3}\right)\right]$ complexes, ${ }^{20}$ there is good correlation between this and the single $v_{\text {co }}$ value for the complexes 1 (Chart 3).

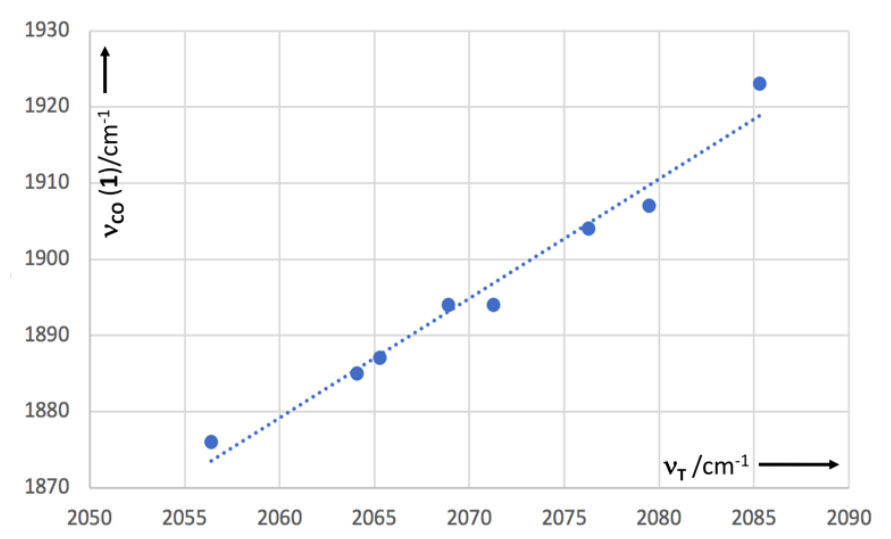

Chart 3. Correlation of $v_{\mathrm{co}}$ for ruthenaboratranes (1) vs Tolman's Electronic Parameter $\boldsymbol{v}_{\mathrm{T}}$. $\left[\mathrm{Ni}\left(\mathrm{CN}^{t} \mathrm{Bu}\right)(\mathrm{CO})_{3}\right]$ has not been reported, the value used here is for $\left[\mathrm{Ni}\left(\mathrm{CN}^{n} \mathrm{Bu}\right)(\mathrm{CO})_{3}\right] . .^{22}$

Chart 4 presents Ru-B bond lengths in relation to the $v_{\mathrm{CO}}$ values for ruthenaboratranes. The isonitrile and phosphite ligands have the capacity to act as $\pi$-acceptors and the three derived complexes display the longest $\mathrm{Ru}-\mathrm{B}$ bond lengths, however the $\mathrm{PMe}_{2} \mathrm{Ph}$ derivative $1 \mathrm{f}$ has a $\mathrm{Ru}-\mathrm{B}$ bond length comparable to that of the $\mathrm{CN}^{t} \mathrm{Bu}$ and $\mathrm{P}(\mathrm{OEt})_{3}$ derivatives, but considerably longer than found in the $\mathrm{PMe}_{3}$ derivative (1i) despite $\mathrm{PMe}_{3}$ and $\mathrm{PMe}_{2} \mathrm{Ph}$ having rather similar $\boldsymbol{v}_{\mathrm{T}}$ values.

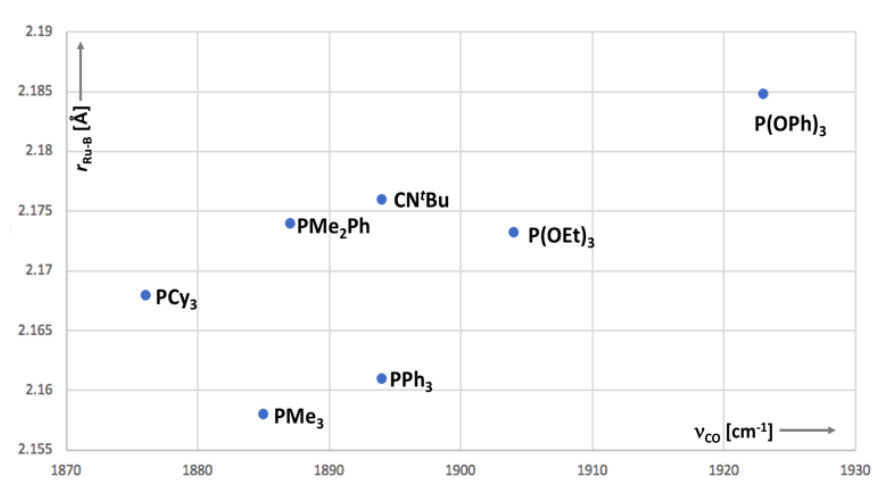

Chart 4. Relationship between Ru-B bond length and $v_{\mathrm{CO}}$ for ruthenaboratranes (1)

Although $\mathrm{PCy}_{3}$ is considered more electron releasing than $\mathrm{PMe}_{3}$, the $\mathrm{Ru}-\mathrm{B}$ bond length in the $\mathrm{PCy}_{3}$ derivative $\mathbf{1 g}$ is intermediate between those for the $\mathrm{PMe}_{3}(\mathbf{1} \mathbf{h})$ and $\mathrm{PMe}_{2} \mathrm{Ph}$ (1f) derivatives (Chart 4), presumably due to the more pronounced inter ligand repulsion in the $\mathrm{PCy}_{3}$ complex. Steric factors should be more pronounced in octahedral ruthenium complexes than in tetrahedral $\left[\mathrm{Ni}(\mathrm{CO})_{3}\left(\mathrm{PR}_{3}\right)\right]$ and the selection of phosphines spans a wide range $\left(107<\theta_{\top}<170^{\circ}\right)$. Figure 7 presents space filling representations for the phosphines considered in addition to the two previously reported isonitrile derivatives $\left[\mathrm{Ru}(\mathrm{CO})(\mathrm{CNR})\left\{\mathrm{B}(\mathrm{mt})_{3}\right\}\right] \quad\left(\mathrm{R}={ }^{t} \mathrm{Bu}, \mathrm{C}_{6} \mathrm{H}_{2} \mathrm{Me}_{3}-2,4,6\right) .{ }^{3 \mathrm{c}}$ Whilst isonitriles are clearly more slender ligands than the vast majority of phosphines, they also present a variable degree of $\pi$-acidity depending on the nature of the alkyl or aryl substituent.
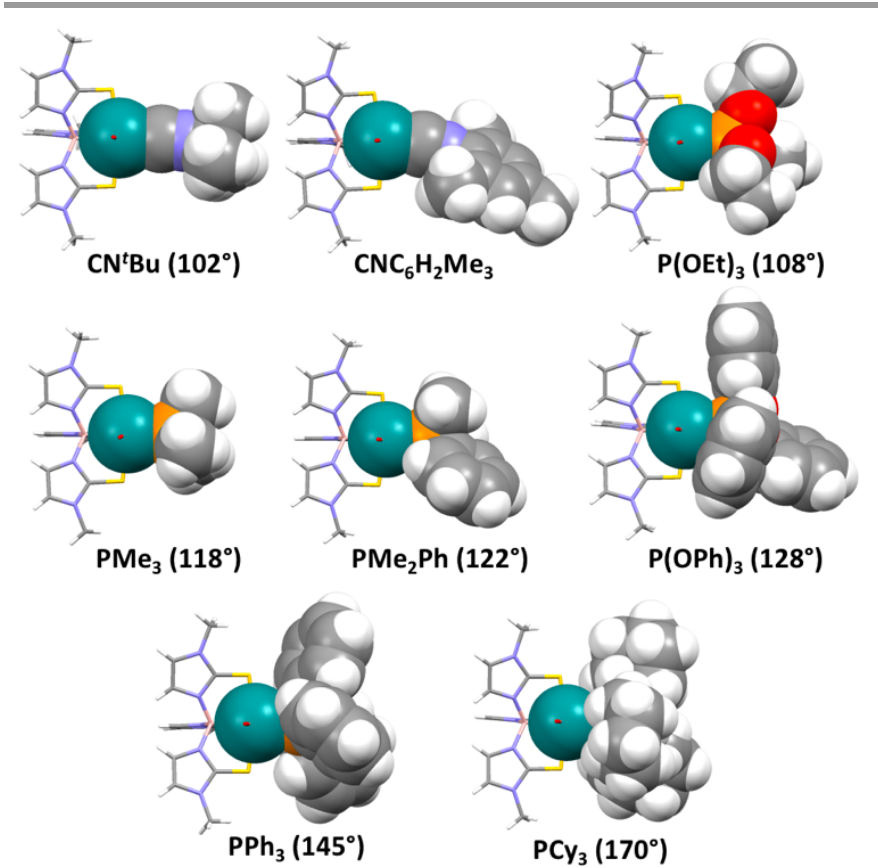

Figure 7. Space-filling representations of ligands bound to the ' $\mathrm{Ru}(\mathrm{CO})\left\{\mathrm{B}(\mathrm{mt})_{3}\right\}^{\prime}$ 'viewed along the unique $\mathrm{Ru}-\mathrm{C}$ vector with associated Tolman cone angles $\left(\boldsymbol{\theta}_{\mathrm{T}}\right)$.

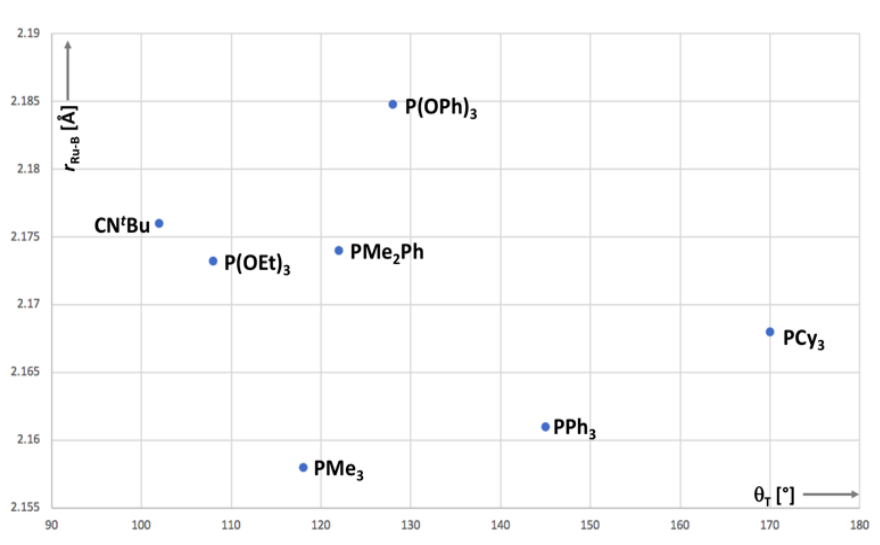

Chart 5. Relationship of ruthenaboratrane Ru-B bond length towards $\theta_{\mathrm{T}}$ for phosphines (1)

Finally, it may be noted that there is no useful correlation between the $\mathrm{Ru}-\mathrm{S}$ bond lengths and either the Tolman cone angle or the Ru-B bond length (See Supporting Information, Chart S1), as might be expected given the comparatively narrow ranges spanned (trans-S-Ru-S: $2.478-2.510=0.032 \AA$; trans-LRu-S: $2.398-2.417=0.02 \AA$; Ru-B: $2.157-2.184=0.027 \AA$ ) and the typical precision in these bond lengths $(6 \times$ e.s.d. $=c a 0.004$ $-0.011(\mathrm{Ru}-\mathrm{S})$ and $0.018-0.036 \AA$ $)$. In all cases, however, the 
unique Ru-S bond length is significantly longer ( $c a 0.08 \AA$ ) than the average of the two mutually trans disposed Ru-S bonds.

\section{Conclusions}

Despite significantly extending the range of known ruthenaboratranes and acquiring both spectroscopic and crystallographic data for many, not a single parameter emerges as a definitive measure of the variable degree of $\mathrm{Ru} \rightarrow \mathrm{B}$ interaction. The Tolman steric and electronic parameters are independent variables that may reinforce or counteract each other with respect to the Ru-B bond length (and by implication, bond strength). Whilst the bridgehead boron nuclei give rise to resonances in a region of the ${ }^{11} \mathrm{~B}$ NMR spectra appropriate for four-coordinate boron, these span a remarkably small range and are exacerbated by the typically broad appearance of resonances. Each example includes a carbonyl ligand coordinated cis to both the variable phosphine and the borane boron, however other than correlating, as expected with the Tolman electronic parameter, ${ }^{20}$ the values for $v_{\mathrm{co}}$, which span almost $50 \mathrm{~cm}^{-1}$ for the series, show no significant correlation with geometric parameters such as $r_{\mathrm{RuB}}$. There is a rather loose inverse correlation between $r_{\text {RuB }}$ and $r_{\text {RuP }}$, however this may well be a response to steric rather than electronic factors. That said, the shortest Ru-B separation observed amongst the phosphine/phosphite series corresponds to the smallest and most $\sigma$-basic $\mathrm{PMe}_{3}$ derivative. The shortest case overall however involves the isonitrile $\mathrm{CNC}_{6} \mathrm{H}_{2} \mathrm{Me}_{3}-2,4,6$ which has a Tolman 'cone angle' estimated to be comparable $\left(116^{\circ}\right)$ to $\mathrm{PMe}_{3}$ $\left(118^{\circ}\right)$ although somewhat less electron releasing due to a degree of synergic $\sigma$-donor/ $\pi$-acceptor bonding.

We are therefore at this stage forced to resort to the chemists' standard conclusion; a subtle interplay of steric and electronic factors.

\section{Experimental}

General Considerations. Unless otherwise stated, all experimental work was carried out at room temperature under a dry and oxygen-free nitrogen atmosphere using standard Schlenk, vacuum line and inert atmosphere (argon) dry-box techniques. Solvents tetrahydrofuran, toluene, pentane and hexane were dried and distilled under a nitrogen atmosphere from benzophenone and sodium. Dichloromethane was dried and distilled under a nitrogen atmosphere from calcium hydride. The silica gel used for chromatography was dried in an oven at $100^{\circ} \mathrm{C}$, evacuated and saturated with nitrogen prior to use. Once isolated, compounds were generally stored as solids under a nitrogen or argon atmosphere at $-20^{\circ} \mathrm{C}$. NMR spectra were obtained at $25^{\circ} \mathrm{C}$ on Jeol JNM EX $270\left({ }^{1} \mathrm{H}\right.$ at $270.0,{ }^{13} \mathrm{C}$ at $67.9 \mathrm{MHz},{ }^{11} \mathrm{~B}$ at 86.6, ${ }^{31} \mathrm{P}$ at $\left.109.3 \mathrm{MHz}\right)$, Bruker AVANCE 400 $\left({ }^{1} \mathrm{H}\right.$ at $\left.399.9 \mathrm{MHz}\right)$, Bruker AVANCE $600\left({ }^{1} \mathrm{H}\right.$ at $600.0,{ }^{13} \mathrm{C} N M R$ at $150.9 \mathrm{MHz})$ or Bruker AVANCE $800\left({ }^{1} \mathrm{H}\right.$ at $800.1,{ }^{13} \mathrm{C}$ NMR at $201.0 \mathrm{MHz}$ ) spectrometers. Chemical shifts $(\delta)$ are reported in ppm and referenced to the solvent peaks or external standards ( ${ }^{31} \mathrm{P}: 70 \% \mathrm{H}_{3} \mathrm{PO}_{4} ;{ }^{11} \mathrm{~B}: \mathrm{BF}_{3} \cdot \mathrm{OEt}_{2}$ ). The multiplicities of $\mathrm{NMR}$ resonances are denoted by the abbreviations $s$ (singlet), $d$ (doublet), $\mathrm{t}$ (triplet), $\mathrm{m}$ (multiplet) and combinations thereof for more highly coupled systems. Infrared spectra were obtained using a Perkin-Elmer $1720-X$ or Spectrum One FT-IR spectrometers. FAB mass spectra were obtained from 3nitrobenzylalocohol matrices with Kratos MS-80 or Autospec- $Q$ instrument. Electrospray ionisation mass spectrometry (ESI-MS) was performed by the ANU Research School of Chemistry mass spectrometry service with acetonitrile as the matrix. With the exception of complexes $\mathbf{1} \mathbf{h}, \mathbf{1} \mathbf{j}$ and $\mathbf{1 k}$, data for X-ray crystallography were collected on Nonius Kappa KappaCCD, Oxford Diffraction Xcalibur or SuperNova diffractometers. Diffraction data for complexes $\mathbf{1} \mathbf{h}, \mathbf{1} \mathbf{j}$ and $\mathbf{1 k}$ were collected some years ago at room temperature on a Siemens P4 diffractometer using sealed tube $X$-ray sources and single point counter detectors. As such, the data beyond $2 \theta \mathrm{ca} 120^{\circ}$ with copper radiation, or ca $45^{\circ}$ with molybdenum radiation was typically too weak and diffuse to be observable in a sensible time frame, and so the standard data collections did not proceed beyond these angles. The compounds $\left[\mathrm{RuCl}(\mathrm{R})(\mathrm{CO})\left(\mathrm{PPh}_{3}\right)_{2}\right]\left(\mathrm{R}=\mathrm{Ph},{ }^{17} \mathrm{CH}=\mathrm{CHPh}^{18}\right)$ were prepared according to published procedures. All other reagents were obtained from commercial sources.

Synthesis of $\left[\mathrm{Ru}(\mathrm{CO})\left(\mathrm{PMe} \mathbf{2}_{2} \mathrm{Ph}\right)\left\{\mathrm{B}(\mathrm{mt})_{3}\right\}\right](\mathbf{1 f})$. Method 1: To a solution of $\left[\mathrm{Ru}(\mathrm{CO})\left(\mathrm{PPh}_{3}\right)\left\{\mathrm{B}(\mathrm{mt})_{3}\right\}\right](1 \mathrm{a}: 0.50 \mathrm{~g}, 0.68 \mathrm{mmol})$ in dichloromethane $(50 \mathrm{~mL})$ was added an excess of $\mathrm{PMe}_{2} \mathrm{Ph}(0.12$ $\mathrm{g}, 0.12 \mathrm{~mL}, 0.87 \mathrm{mmol}$ ) under an inert atmosphere. The mixture was stirred for 1 hour and then the solvent was reduced and a yellow precipitate was formed on addition of ethanol $(20 \mathrm{~mL})$. The product was isolated by filtration, washed with ethanol $(2 \mathrm{x}$ $10 \mathrm{~mL})$ and hexane $(10 \mathrm{~mL})$ and dried in vacuo. Yield $=0.31 \mathrm{~g}$ (0.51 mmol, 74\%). Method 2: A mixture of $\left[\mathrm{Ru}(\mathrm{CH}=\mathrm{CHPh}) \mathrm{Cl}(\mathrm{CO})\left(\mathrm{PMe}_{2} \mathrm{Ph}\right)_{3}\right]($ 3: $0.41 \mathrm{~g}, 0.60 \mathrm{mmol})$ and $\mathrm{Na}\left[\mathrm{HB}(\mathrm{mt})_{3}\right](0.23 \mathrm{~g}, 0.61 \mathrm{mmol})$ was heated under reflux in THF $(30 \mathrm{~mL})$ for 12 hours. The mixture was allowed to cool and then filtered. The filtrate was concentrated under reduced pressure (ca $5 \mathrm{~mL}$ ) and then diluted with hexane $(20 \mathrm{~mL}$ ) resulting in the formation of a yellow precipitate. The product was filtered off and washed with diethyl ether $(2 \times 20 \mathrm{~mL})$ and further recrystallised from a mixture of $\mathrm{CH}_{2} \mathrm{Cl}_{2}$ and ethanol. The resulting product was washed with petroleum ether $\left(60-80^{\circ} \mathrm{C}\right)$ $(20 \mathrm{~mL})$ and then diethyl ether $(10 \mathrm{~mL})$ dried in vacuo. Yield $=$ $0.19 \mathrm{~g}(0.31 \mathrm{mmol}, 51 \%)$. [NB: The reaction does not proceed to completion at room temperature]. IR $\left(\mathrm{cm}^{-1}\right)$ Nujol: $1883 v_{\mathrm{CO}}$, 1552w, 1181s, 1041m, 937m, 897m. ATR: 3115, 2970, $1882 v_{\text {co. }}$ $\mathrm{CH}_{2} \mathrm{Cl}_{2}: 1887 v_{\mathrm{CO}} .{ }^{1} \mathrm{H} \mathrm{NMR}\left(300.7 \mathrm{MHz}, \mathrm{CDCl}_{3}\right): \delta_{\mathrm{H}}=2.01(\mathrm{~d}, 6 \mathrm{H}$, $\left.2 J_{\mathrm{PH}}=5, \mathrm{PCH}_{3}\right), 3.65\left(\mathrm{~s}, 6 \mathrm{H}, \mathrm{NCH}_{3}\right), 3.73\left(\mathrm{~s}, 3 \mathrm{H}, \mathrm{NCH}_{3}\right), 6.14,6.39$ $\left(\mathrm{d} \times 2,2 \mathrm{H} \times 2,3 \mathrm{~J}_{\mathrm{HH}}=1.9, \mathrm{NCH}=\mathrm{CHN}\right), 6.48,6.70(\mathrm{~d} \times 2,1 \mathrm{H} \times 2$, $\left.3 J_{\mathrm{HH}}=1.9 \mathrm{~Hz}, \mathrm{NCH}=\mathrm{CHN}\right), 7.11,7.24,7.54\left(\mathrm{~m} \times 3,5 \mathrm{H}, \mathrm{C}_{6} \mathrm{H}_{5}\right)$. ${ }^{13} \mathrm{C}\left\{{ }^{1} \mathrm{H}\right\} \mathrm{NMR}\left(75.4 \mathrm{MHz}, \mathrm{CDCl}_{3}\right): \delta_{\mathrm{C}}=18.40\left(\mathrm{~d},{ }^{1} J_{\mathrm{PC}}=15.4, \mathrm{PCH}_{3}\right)$, $33.7\left(2 \mathrm{C}, \mathrm{NCH}_{3}\right), 34.2\left(1 \mathrm{C}, \mathrm{NCH}_{3}\right), 116.3,117.4(\mathrm{NCH}=\mathrm{CHN})$, $120.8,122.1\left[\mathrm{C}^{4}\left(\mathrm{C}_{6} \mathrm{H}_{5}\right)\right], 127.9\left[\mathrm{~d},{ }^{3} \mathrm{JPC}_{\mathrm{PC}}=4.6, \mathrm{C}^{3,5}\left(\mathrm{C}_{6} \mathrm{H}_{5}\right)\right], 128.0$ $\left[\mathrm{C}^{4}\left(\mathrm{C}_{6} \mathrm{H}_{5}\right)\right], 130.3\left[\mathrm{~d},{ }^{2} \mathrm{~J}_{\mathrm{PC}}=12.8, \mathrm{C}^{2,6}\left(\mathrm{C}_{6} \mathrm{H}_{5}\right)\right], 142.3\left[\mathrm{~d},{ }^{1} J_{\mathrm{PC}}=19.8\right.$, $\left.\mathrm{C}^{1}\left(\mathrm{C}_{6} \mathrm{H}_{5}\right)\right], 170.9$ (1C, CS), 171.1 (2C, CS), 206.5 (RuCO). ${ }^{13} \mathrm{C}\left\{{ }^{1} \mathrm{H}\right\}$ $\left(176 \mathrm{MHz}, \mathrm{CDCl}_{3}\right): \delta_{\mathrm{C}} 18.6\left(\mathrm{~d}, 1_{\mathrm{PC}}=15.8, \mathrm{PCH}_{3}\right), 33.7,34.2(\mathrm{NCH}-$ 3), $116.5\left(\mathrm{~d}, 4 J_{\mathrm{PC}}=2.3, \mathrm{NCH}=\mathrm{CHN}\right), 116.6\left(\mathrm{~d}, 4 J_{\mathrm{PC}}=1.7\right.$, $\mathrm{NCH}=\mathrm{CHN}), 122.2\left[\mathrm{C}_{4}\left(\mathrm{C}_{6} \mathrm{H}_{5}\right)\right], 128.0,128.1(\mathrm{NCH}=\mathrm{CHN}), 128.0[\mathrm{~d}$, $\left.3 J_{\mathrm{PC}}=7.9, \mathrm{C}^{3,5}\left(\mathrm{C}_{6} \mathrm{H}_{5}\right)\right], 130.3\left[\mathrm{~d}, 2 \mathrm{~J}_{\mathrm{PC}}=12.3, \mathrm{C}^{2,6}\left(\mathrm{C}_{6} \mathrm{H}_{5}\right)\right], 142.2[\mathrm{~d}$, $\left.{ }^{1} J_{\mathrm{PC}}=19.4, \mathrm{C}^{1}\left(\mathrm{C}_{6} \mathrm{H}_{5}\right)\right], 166.8\left(\mathrm{~d},{ }^{3} J_{\mathrm{PC}}=22.9, \mathrm{CS}\right), 170.1\left(\mathrm{~d},{ }^{3} J_{\mathrm{PC}}=\right.$ 
17.6, CS), 206.7 (d, $\left.{ }^{2} J_{\mathrm{PC}}=5.3 \mathrm{~Hz}, \mathrm{CO}\right) .{ }^{31} \mathrm{P}\left\{{ }^{1} \mathrm{H}\right\} \mathrm{NMR}(283 \mathrm{MHz}$, $\left.\mathrm{CDCl}_{3}\right): \delta \mathrm{P}=-13.3$ (br s). ${ }^{11} \mathrm{~B}\left\{{ }^{1} \mathrm{H}\right\}$ NMR $\left(128 \mathrm{MHz}, \mathrm{CDCl}_{3}\right): \delta_{\mathrm{B}}=$ 15.4 (br s). FAB-MS: $m / z(\%): 619(25)[\mathrm{M}]^{+}, 591(10 \%)[\mathrm{M}-\mathrm{CO}]^{+}$, 452(40\%)[M-CO-PMe $\left.{ }_{2} \mathrm{Ph}\right]^{+}$. ESI-MS (+) $\quad \mathrm{m} / \mathrm{z}: 618.0 \quad[\mathrm{M}]^{+}$. Accurate mass: Found $618.0201\left[^{\mathrm{M}]^{+}}\right.$, Calcd. for $\mathrm{C}_{21} \mathrm{H}_{26}{ }^{11} \mathrm{BN}_{6} \mathrm{OPS}_{3}{ }^{102} \mathrm{Ru}$ 618.0204; Found 641.0121 [M+Na] $]^{+}$, Calcd. for $\mathrm{C}_{21} \mathrm{H}_{26}{ }^{11} \mathrm{BN}_{6} \mathrm{O}^{23} \mathrm{NaPS}_{3}{ }^{102} \mathrm{Ru}$ 641.0102; Found $1258.0226 \quad[\mathrm{M}-\mathrm{H}+\mathrm{Na}]^{+}$. Calcd. for $\mathrm{C}_{42} \mathrm{H}_{51}{ }^{11} \mathrm{~B}_{2} \mathrm{~N}_{12} \mathrm{O}_{2-}$ ${ }^{23} \mathrm{NaP}_{2} \mathrm{~S}_{6}{ }^{102} \mathrm{Ru}_{2}$ 1258.0228. Anal. Found: $\mathrm{C}, 40.91 ; \mathrm{H}, 4.18 ; \mathrm{N}$, 13.49\%. Calcd. for $\mathrm{C}_{21} \mathrm{H}_{26} \mathrm{BN}_{6} \mathrm{OPRuS}_{3}$ : C, 40.85; $\mathrm{H}, 4.24 ; \mathrm{N}$, $13.61 \%$.

Crystals suitable for crystallographic analysis were obtained from slow evaporation of a concentrated solution in dichloromethane/n-pentane over one day. Crystal data for $\mathrm{C}_{21} \mathrm{H}_{26} \mathrm{BN}_{6} \mathrm{OPRuS}_{3}: M_{\mathrm{w}}=617.53$, monoclinic, $P 2_{1} / \mathrm{c}, a=$ $14.4644(2), b=14.2915(2), c=13.0253(1) \AA, \beta=102.2830(13)^{\circ}$, $V=2630.93(2) \AA^{3}, Z=4, D_{\text {calcd. }}=1.559 \mathrm{Mg} \mathrm{m}^{-3}, \mu(\mathrm{Cu} \mathrm{K} \alpha)=7.84$ $\mathrm{mm}^{-1}, T=150(2) \mathrm{K}$, yellow block, $0.39 \times 0.19 \times 0.09 \mathrm{~mm}, 5,301$ independent reflections. $F^{2}$ refinement, $R_{1}=0.035, w R_{2}=0.095$ for 4,954 reflections $\left(I>2.0 \sigma(I), 2 \theta_{\max }=144 \%\right)$, 307 parameters, 42 restraints, CCDC 1874175.

Synthesis of $\left[\mathrm{Ru}(\mathrm{CO})\left(\mathrm{PC}_{3}\right)\left\{\mathrm{B}(\mathrm{mt})_{3}\right\}\right]$ (1g). A mixture of [RuCl$\left.(\mathrm{Ph}) \mathrm{Cl}(\mathrm{CO})\left(\mathrm{PCy}_{3}\right)_{2}\right](4: 0.50 \mathrm{~g}, 0.62 \mathrm{mmol})$ and $\mathrm{Na}\left[\mathrm{HB}(\mathrm{mt})_{3}\right]$ ( $0.23 \mathrm{~g}, 0.62 \mathrm{mmol})$ was stirred in $\mathrm{CH}_{2} \mathrm{Cl}_{2}(30 \mathrm{~mL})$ for 2 hours. The clear yellow solution was filtered through diatomaceous earth and the solvent volume of the filtrate was reduced to $c a$ $5 \mathrm{~mL}$. Hexane $(20 \mathrm{~mL})$ was added and the total volume reduced slowly to provide a pale yellow precipitate. The product was isolated by filtration and recrystallised from a mixture of $\mathrm{CH}_{2} \mathrm{Cl}_{2}$ and ethanol, isolated by filtration, washed with diethyl ether (20 $\mathrm{mL}$ ) and dried in vacuo. Yield $=0.36 \mathrm{~g}(77 \%) . \mathrm{IR}\left(\mathrm{cm}^{-1}\right)$ Nujol: $1872 v_{\text {CO, }} 1554 w, 1181 v s, 1090 m$ 920w. $\mathrm{CH}_{2} \mathrm{Cl}_{2}$ : $1876 v_{\mathrm{CO}}$. ATR: $2923 \mathrm{w}, 2847 \mathrm{w}, 1871 v_{\mathrm{cO}}{ }^{1} \mathrm{H} \mathrm{NMR}\left(300.7 \mathrm{MHz}, \mathrm{CDCl}_{3}\right): \delta_{\mathrm{H}}=1.23$ - 2.05 (m.br., $33 \mathrm{H}, \mathrm{C}_{6} \mathrm{H}_{11}$ ), 3.46 (s, $6 \mathrm{H}, \mathrm{NCH}_{3}$ ), 3.50 (s, $3 \mathrm{H}, \mathrm{NCH}_{3}$ ), $6.33,6.48\left(\mathrm{~d} \times 2,2 \mathrm{H},{ }^{3} \mathrm{JHH}_{\mathrm{HH}}=1.8, \mathrm{NCH}=\mathrm{CHN}\right), 6.66,6.93(\mathrm{~d} \times 2$, $\left.{ }^{3} J_{\mathrm{HH}}=2.0 \mathrm{~Hz}, 4 \mathrm{H}, \mathrm{NCH}=\mathrm{CHN}\right) \mathrm{ppm} .{ }^{1} \mathrm{H} \mathrm{NMR}\left(700 \mathrm{MHz}, \mathrm{CDCl}_{3}\right): \delta_{\mathrm{H}}$ $=1.30-2.07$ (sets of $\left.\mathrm{m}, 33 \mathrm{H}, \mathrm{C}_{6} \mathrm{H}_{11}\right), 3.46\left(\mathrm{~s}, 3 \mathrm{H}, \mathrm{NCH}_{3}\right), 3.48(\mathrm{~s}$, $\left.6 \mathrm{H}, \mathrm{NCH}_{3}\right), 6.37\left(\mathrm{~d}, 1 \mathrm{H}, 3 \mathrm{~J}_{\mathrm{HH}}=2.1, \mathrm{NCH}=\mathrm{CHN}\right), 6.50\left(\mathrm{~d}, 1 \mathrm{H}, 3^{3} \mathrm{JH}_{\mathrm{H}}\right.$ $=1.7, \mathrm{NCH}=\mathrm{CHN}), 6.70\left(\mathrm{~d}, 2 \mathrm{H},{ }^{3} \mathrm{JHH}_{\mathrm{HH}}=1.8, \mathrm{NCH}=\mathrm{CHN}\right), 6.99(\mathrm{~d}, 1$ $\left.\mathrm{H},{ }^{3} J_{\mathrm{HH}}=2.0, \mathrm{NCH}=\mathrm{CHN}\right) .{ }^{13} \mathrm{C}\left\{{ }^{1} \mathrm{H}\right\}$ APT NMR $\left(100 \mathrm{MHz}, \mathrm{CDCl}_{3}\right): \delta_{\mathrm{C}}$ $=26.9\left[\mathrm{CH}_{2}\left(\mathrm{C}_{6} \mathrm{H}_{11}\right)\right], 28.1\left[\mathrm{~d},{ }^{2} J_{\mathrm{PC}}=9.4, \mathrm{CH}_{2}\left(\mathrm{C}_{6} \mathrm{H}_{11}\right)\right], 29.9\left[\mathrm{~d},{ }^{2} J_{\mathrm{PC}}=\right.$ 2.2, $\left.\mathrm{CH}_{2}\left(\mathrm{C}_{6} \mathrm{H}_{11}\right)\right], 33.9,34.4\left(\mathrm{NCH}_{3}\right), 35.3\left[\mathrm{~d},{ }^{1} J_{\mathrm{PC}}=6.3\right.$, $\mathrm{PCH}\left(\mathrm{C}_{6} \mathrm{H}_{11}\right)$ ], $116.3\left(\mathrm{~d},{ }^{4} J_{\mathrm{PC}}=1.8, \mathrm{NCH}=\mathrm{CHN}\right), 116.5\left(\mathrm{~d},{ }^{4} J_{\mathrm{PC}}=1.2\right.$, $\mathrm{NCH}=\mathrm{CHN}), 121.9,122.0(\mathrm{NCH}=\mathrm{CHN}), 166.8\left(\mathrm{~d}, 3 \mathrm{~J}_{\mathrm{PC}}=17.8, \mathrm{CS}\right)$, $171.0\left(\mathrm{~d},{ }^{3} \mathrm{JC}_{\mathrm{PC}}=13.5 \mathrm{~Hz}, \mathrm{CS}\right), 208.2(\mathrm{CO}) .{ }^{31} \mathrm{P}\left\{{ }^{1} \mathrm{H}\right\} \mathrm{NMR}(283 \mathrm{MHz}$, $\left.\mathrm{CDCl}_{3}\right): \delta_{\mathrm{P}}=28.2$ (br s). ${ }^{11} \mathrm{~B}\left\{{ }^{1} \mathrm{H}\right\} \mathrm{NMR}\left(128 \mathrm{MHz}, \mathrm{CDCl}_{3}\right): \delta_{\mathrm{B}}=15.4$ (br s). ESI-MS (+) m/z: $760.2[\mathrm{M}]^{+}, 783.2[\mathrm{M}+\mathrm{Na}]^{+}$. Accurate mass: Found $760.1951[\mathrm{M}]^{+}$, Calcd. for $\mathrm{C}_{31} \mathrm{H}_{48}{ }^{11} \mathrm{BN}_{6} \mathrm{OPS}_{3}{ }^{102} \mathrm{Ru}$ 760.1926. Found 783.1813 [M+Na ${ }^{+}$, Calcd. for $\mathrm{C}_{31} \mathrm{H}_{48}{ }^{11} \mathrm{BN}_{6} \mathrm{O}^{23} \mathrm{NaPS}_{3}{ }^{102} \mathrm{Ru}$ 783.1824. Anal. Found: $\mathrm{C}, 49.24 ; \mathrm{H}$, 6.36; N, 11.16\%. Calcd. for $\mathrm{C}_{31} \mathrm{H}_{48} \mathrm{BN}_{6} \mathrm{OPS}_{3} \mathrm{Ru}$ : C, 49.00; $\mathrm{H}, 6.37$; $\mathrm{N}, 11.06 \%$. Crystals suitable for crystallographic analysis were obtained from slow evaporation of a concentrated solution in dichloromethane/n-pentane over one day. Crystal data for $\mathrm{C}_{31} \mathrm{H}_{48} \mathrm{BN}_{6} \mathrm{OPRuS}_{3} . \mathrm{CH}_{2} \mathrm{Cl}_{2}(150 \mathrm{~K}): M w=844.75$, triclinic, $P-1$ (No. 2), $a=11.5008(5), b=12.1448(5), c=14.2700(4) \AA, \alpha=$ 82.893(3), $\beta=81.948(3), \gamma=75.012(4)^{\circ}, V=1898.38(5) \AA^{3}, Z=$ $2, D_{\text {calcd. }}=1.478 \mathrm{Mgm}^{-3}, \mu(\mathrm{Cu} \mathrm{K} \alpha)=6.86 \mathrm{~mm}^{-1}, T=150(2) \mathrm{K}$, colourless needle, $0.28 \times 0.06 \times 0.04 \mathrm{~mm}, 7,649$ independent reflections, $F^{2}$ refinement, $R_{1}=0.041, w R_{2}=0.106$ for 6,878 reflections $\left(I>2.0 \sigma(I), 2 \theta_{\max .}=144^{\circ}\right), 442$ parameters, 0 restraints CCDC 1874176.

Synthesis of $\left[\mathrm{Ru}(\mathrm{CO})\left(\mathrm{PMe}_{3}\right)\left\{\mathrm{B}(\mathrm{mt})_{3}\right\}\right](\mathrm{hh})-\mathrm{A}$ solution of $\left[\mathrm{Ru}(\mathrm{CO})\left(\mathrm{PPh}_{3}\right)\left\{\mathrm{B}(\mathrm{mt})_{3}\right\}\right]$ (1a: $\left.1.005 \mathrm{~g}, 1.36 \mathrm{mmol}\right)$ in $\mathrm{CH}_{2} \mathrm{Cl}_{2}(20$ $\mathrm{mL})$ was treated with a solution of $\mathrm{PMe}_{3}(0.12 \mathrm{~g}, 1.50 \mathrm{mmol})$ in THF $(10 \mathrm{~mL})$ and the mixture stirred for 16 hours. Diethyl ether $(40 \mathrm{~mL})$ was added to provide a pale yellow precipitate which was freed of supernatant by cannula filtration. The residue was recrystallised from a mixture of dichloromethane and ethanol. Yield 0.625g (1.12 mmol, 83\%). IR (cm $\left.{ }^{-1}\right)$ Nujol: $1993 v_{\mathrm{CO}}, 1554 \mathrm{w}$, 1181s, 944.9m. IR (cm $\left.{ }^{-1}\right) \mathrm{CH}_{2} \mathrm{Cl}_{2}: 1885 v_{\mathrm{co}}{ }^{1} \mathrm{H} \mathrm{NMR}(270 \mathrm{MHz}$, $\left.\mathrm{CDCl}_{3}\right) ; \delta=1.43\left(\mathrm{~d}, 9 \mathrm{H},{ }^{2} J_{\mathrm{PH}}=5.4 \mathrm{~Hz}, \mathrm{PCH}_{3}\right) 3.42(\mathrm{~s}, 3 \mathrm{H} ; \mathrm{NCH} 3)$, $3.43(\mathrm{~s}, 6 \mathrm{H}, \mathrm{NCH} 3), 6.36,6.54\left(\mathrm{~d} \times 2,1 \mathrm{H} \times 2,{ }^{3} \mathrm{~J}_{\mathrm{HH}}\right.$ not resolved, $\mathrm{NHC}=\mathrm{CHN}), 6.70,6.96\left(\mathrm{~d} \times 2,2 \mathrm{H} \times 2,3 \mathrm{~J}_{\mathrm{HH}}\right.$ not resolved, $\mathrm{NHC}=\mathrm{CHN})$ ppm. ${ }^{13} \mathrm{C}\left\{{ }^{1} \mathrm{H}\right\} \mathrm{NMR}\left(67.9 \mathrm{MHz}, \mathrm{CDCl}_{3}\right): \delta_{\mathrm{C}}=19.51(\mathrm{~d}$, $\left.1 J_{\mathrm{PC}}=15.5, \mathrm{PCH}_{3}\right), 33.7,34.2\left(\mathrm{NCH}_{3}\right), 116.5,122.1$ ( $\left.\mathrm{NCHCHN}\right)$, 171.3, 171.6 (CS), 206.9 (RuCO). ${ }^{31} \mathrm{P}\left\{{ }^{1} \mathrm{H}\right\} \mathrm{NMR}\left(72.9 \mathrm{~Hz}, \mathrm{CDCl}_{3}\right)$ : $\delta_{\mathrm{P}}=-25.2$ (s.br.). ${ }^{11} \mathrm{~B}\left\{{ }^{1} \mathrm{H}\right\} \mathrm{NMR}\left(86.6 \mathrm{MHz}, \mathrm{CDCl}_{3}\right): \delta_{\mathrm{B}}=14.6$ (br.). LR-FAB-MS (nba matrix): $m / z=556(12)[\mathrm{M}]^{+}, 528(29)[\mathrm{M}-\mathrm{CO}]^{+}$, 452(53) [M-CO-PMe $]_{3}^{+}$. Anal. Found; C, 34.23; $\mathrm{H}, 4.59 ; \mathrm{N}$, $14.88 \%$. Calc. for $\mathrm{C}_{16} \mathrm{H}_{24} \mathrm{BN}_{6} \mathrm{OPRuS}_{3} \mathrm{C}, 34.58 ; \mathrm{H}, 4.36 ; \mathrm{N}, 15.13 \%$ : Crystals suitable for crystallographic analysis were obtained from slow evaporation of a concentrated solution in dichloromethane/n-pentane. Crystal data for $\mathbf{1 h}$ : $\mathrm{C}_{16} \mathrm{H}_{24} \mathrm{BN}_{6} \mathrm{OPRuS}_{3}, M_{\mathrm{w}}=555.44$, monoclinic, $P 2_{1} / c$ (no. 14), $a=$ 13.763(2), $b=12.5156(18), c=13.792(3) \AA, \beta=95.727(14)^{\circ}, V=$ 2364.0(7) $\AA^{3}, Z=4, D_{\text {calcd. }}=1.561 \mathrm{Mg} \mathrm{m}^{-3}, \mu(\mathrm{Mo}-\mathrm{K \alpha} \alpha)=1.016 \mathrm{~mm}^{-}$ $1, T=293 \mathrm{~K}$, yellow prisms, 3,079 independent measured reflections $\left(R_{\text {int }}=0.0333\right), F^{2}$ refinement, $R_{1}=0.0390, w R_{2}=$ $0.0871,2,362$ independent observed absorption-corrected reflections $\left[\left|F_{\mathrm{o}}\right|>4 \sigma\left(\left|F_{\mathrm{o}}\right|\right)\right.$, completeness to $\theta_{\text {full }}\left(22.5^{\circ}\right)=$ 100.0\%], 295 parameters. CCDC 1874177. The trimethyl phosphine group in the structure of $\mathbf{1 h}$ was found to be disordered. Three orientations were identified of $c a .46,32$ and $22 \%$ occupancy, their geometries were optimised, the thermal parameters of adjacent atoms were restrained to be similar, and only the three partial occupancy phosphorus atoms were refined anisotropically (the carbon and hydrogen atoms of all three orientations were refined isotropically).

Synthesis of $\left[\mathrm{Ru}(\mathrm{CO})\left\{\mathrm{P}(\mathrm{OMe})_{3}\right\}\left\{\mathrm{B}(\mathrm{mt})_{3}\right\}\right]$ (1i). Method 1: A mixture of $\left[\mathrm{Ru}(\mathrm{CO})\left(\mathrm{PPh}_{3}\right)\left\{\mathrm{B}(\mathrm{mt})_{3}\right\}\right](1 \mathrm{a}: 0.500 \mathrm{~g}, 0.675 \mathrm{mmol})$ and $\mathrm{P}(\mathrm{OMe})_{3}(0.08 \mathrm{~mL}, 0.72 \mathrm{mmol})$ was heated under reflux in hexane $(30 \mathrm{~mL})$ for $16 \mathrm{hrs}$, during which time a colour change from yellow to orange was observed. The solvent was reduced and petroleum spirit added $\left(80-100^{\circ} \mathrm{C}, 20 \mathrm{~mL}\right)$. The solvent volume was further reduced to yield an off-white precipitate. The solid was filtered off, washed with petroleum spirit (60$\left.80^{\circ} \mathrm{C}, 2 \times 20 \mathrm{~mL}\right)$ and dried in vacuo. Yield $=0.27 \mathrm{~g}(0.45 \mathrm{mmol}$, $62 \%)$. Method 2: A mixture of $\left[\mathrm{Ru}(\mathrm{CH}=\mathrm{CHPh}) \mathrm{Cl}(\mathrm{CO})\left\{\mathrm{P}(\mathrm{OMe})_{3}\right\}_{3}\right]$ (5: $0.23 \mathrm{~g}, 0.36 \mathrm{mmol})$ and $\mathrm{Na}\left[\mathrm{HB}(\mathrm{mt})_{3}\right](0.14 \mathrm{~g}, 0.36 \mathrm{mmol})$ was heated under reflux in THF $(30 \mathrm{~mL})$ for 12 hours. The mixture was allowed to cool and the clear yellow solution was filtered through diatomaceous earth. The filtrate was concentrated under reduced pressure to $c a 5 \mathrm{~mL}$ and then hexane added (20 $\mathrm{mL}$ ). The total volume was further reduced and the resulting yellow precipitate was allowed to settle and the mother-liquor 
decanted off. The remaining solid was washed with petroleumether $\left(60-80^{\circ} \mathrm{C}, 20 \mathrm{~mL}\right)$ and diethyl-ether $(10 \mathrm{~mL})$ and then dried in vacuo. Yield $=0.130 \mathrm{~g}(0.22 \mathrm{mmol}, 59 \%)$. NB: This resulting solid is susceptible to forming a gum when the THF solvent is not completely removed during the work-up process. Method 3: A solution of $\left[\mathrm{Ru}(\mathrm{CO})\left(\mathrm{PPh}_{3}\right)\left\{\mathrm{B}(\mathrm{mt})_{3}\right\}\right](1 \mathrm{a}: 0.202 \mathrm{~g}, 0.27 \mathrm{mmol})$ and $\mathrm{P}(\mathrm{OMe})_{3}(0.20 \mathrm{~mL}, 1.64 \mathrm{mmol})$ in THF $(20 \mathrm{~mL})$ was heated under reflux for $16 \mathrm{~h}$. The bright yellow precipitate was separated from the supernatant by cannula filtration, washed with n-pentane and dried in vacuo. Yield: $0.080 \mathrm{~g}(0.133 \mathrm{mmol}$, 49\%). IR (cm $\left.{ }^{-1}\right) \mathrm{CH}_{2} \mathrm{Cl}_{2}$ : 1907 vco. Nujol: $1883 v_{\mathrm{CO}}, 1552 \mathrm{w}, 1181 \mathrm{~s}$, 1041m, 937m, 897m. ATR: 3164w, 3114w, $1894 v_{\mathrm{CO}}, 1556 \mathrm{~m}$, 1184s, 1011v. ${ }^{1} \mathrm{H}$ NMR $\left(300.7 \mathrm{MHz}, \mathrm{CDCl}_{3}\right) \delta_{\mathrm{H}}=3.72(\mathrm{~s}, 6 \mathrm{H}$, $\left.\mathrm{NCH}_{3}\right), 3.73\left(\mathrm{~s}, 3 \mathrm{H}, \mathrm{NCH}_{3}\right), 3.92\left(\mathrm{~d}, 3 \mathrm{~J}_{\mathrm{PH}}=11.5,9 \mathrm{H}, \mathrm{OCH}_{3}\right), 6.34$, $6.57\left(\mathrm{~d} \times 2,3 \mathrm{~J}_{\mathrm{HH}}=1.8,2 \mathrm{H}, \mathrm{NCH}=\mathrm{CHN}\right), 6.64,6.72\left(\mathrm{~d} \times 2,2 \mathrm{H}^{3} \mathrm{~J}_{\mathrm{HH}}\right.$ $=1.8, \mathrm{NCH}=\mathrm{CHN}), 7.00,7.25\left(\mathrm{~d} \times 2,2 \mathrm{H},{ }^{3} \jmath_{\mathrm{HH}}=2.0 \mathrm{~Hz}, \mathrm{NCH}=\mathrm{CHN}\right)$ ppm. ${ }^{13} \mathrm{C}\left\{{ }^{1} \mathrm{H}\right\} \mathrm{NMR}\left(176 \mathrm{MHz}, \mathrm{CDCl}_{3}\right): \delta_{\mathrm{C}}=33.8,34.3\left(\mathrm{NCH}_{3}\right), 50.8$ $\left(\mathrm{OCH}_{3}\right), 116.6\left(\mathrm{~d}, 4 \mathrm{~J}_{\mathrm{PC}}=3.2, \mathrm{NCH}=\mathrm{CHN}\right), 116.7\left(\mathrm{~d},{ }^{4} \mathrm{~J}_{\mathrm{CP}}=2.6\right.$, $\mathrm{NCH}=\mathrm{CHN}), 122.5,122.7(\mathrm{NCH}=\mathrm{CHN}), 167.3\left(\mathrm{~d}, 3 J_{\mathrm{PC}}=27.2, \mathrm{CS}\right)$, $171.0\left(\mathrm{~d},{ }^{3} J_{\mathrm{PC}}=22.1, \mathrm{CS}\right), 206.0\left(\mathrm{~d},{ }^{2} J_{\mathrm{PC}}=7.1 \mathrm{~Hz}, \mathrm{CO}\right) .{ }^{31} \mathrm{P}\left\{{ }^{1} \mathrm{H}\right\} \mathrm{NMR}$ (283 MHz, $\left.\mathrm{CDCl}_{3}\right): \delta_{\mathrm{p}}=159.1$ (br s). ${ }^{11} \mathrm{~B}\left\{{ }^{1} \mathrm{H}\right\} \mathrm{NMR}(128 \mathrm{MHz}$, $\left.\mathrm{CDCl}_{3}\right): \delta_{\mathrm{B}}=14.5$ (br s). LR FAB-MS (nba): $m / z(\%)=603(15)[\mathrm{M}]^{+}$, 575(19) $[\mathrm{M}-\mathrm{CO})]^{+}, 452(44)\left[\mathrm{M}-\mathrm{CO}-\mathrm{P}(\mathrm{OMe})_{3}\right]^{+}$. ESI-MS (+) m/z: $604.0\left[\mathrm{HM}^{+}, 627.0[\mathrm{M}+\mathrm{Na}]^{+}\right.$. Accurate mass: Found 603.9898 $[\mathrm{M}]^{+}$, Calcd. for $\mathrm{C}_{16} \mathrm{H}_{24}{ }^{11} \mathrm{BN}_{6} \mathrm{O}_{4} \mathrm{PS}_{3}{ }^{102} \mathrm{Ru}$ 603.9895. Found $626.9792[\mathrm{M}+\mathrm{Na}]^{+}$, Calcd. for $\mathrm{C}_{16} \mathrm{H}_{24}{ }^{11} \mathrm{BN}_{6} \mathrm{O}_{4}{ }^{23} \mathrm{NaPS}_{3}{ }^{102} \mathrm{Ru}$ 626.9793. Found $1230.9668[2 \mathrm{M}+\mathrm{Na}]^{+}$, Calcd. for $\mathrm{C}_{32} \mathrm{H}_{48}{ }^{11} \mathrm{~B}_{2} \mathrm{~N}_{12} \mathrm{O}_{8}{ }^{23} \mathrm{NaP}_{2} \mathrm{~S}_{6}{ }^{102} \mathrm{Ru}_{2}$ 1230.9688. Anal. Found; $\mathrm{C} 31.94 ;$ $\mathrm{H}, 4.12 ; \mathrm{N}, 13.84 \%$. Calcd. For $\mathrm{C}_{16} \mathrm{H}_{24} \mathrm{O}_{4} \mathrm{~N}_{6} \mathrm{BPRuS}_{3} ; \mathrm{C}, 31.85 ; \mathrm{H}$, 4.01; N, 13.93\%:

Synthesis of $\left[\mathrm{Ru}(\mathrm{CO})\left\{\mathrm{P}(\mathrm{OEt})_{3}\right\}\left\{\mathrm{B}(\mathrm{mt})_{3}\right\}\right](\mathbf{1 j})-A s$ described for 1i above (Method 1, 1a: $1.005 \mathrm{~g}, 1.36 \mathrm{mmol}$ ). Yield $0.756 \mathrm{~g}$ (1.17 mmol, 86\%). IR (cm-1) Nujol: $1898 v_{\mathrm{CO}}, 1553 \mathrm{w}, 1179 \mathrm{~s}$, 1030s, 921m. IR (cm $\left.{ }^{-1}\right) \mathrm{CH}_{2} \mathrm{Cl}_{2}: 1904 v_{\mathrm{co}} .{ }^{1} \mathrm{H} \mathrm{NMR}(270 \mathrm{MHz}$, $\left.\mathrm{CDCl}_{3}\right) ; \delta=1.30\left(\mathrm{dt}, 9 \mathrm{H}, 2 \mathrm{JHH}=7.1,{ }^{4} \mathrm{JH}_{\mathrm{PH}}=0.8, \mathrm{CCH}_{3}\right), 3.46(\mathrm{~s}, 9$ $\left.\mathrm{H} ; \mathrm{NCH}_{3}\right), 4.03\left(\mathrm{dq}, 6 \mathrm{H}, 3 J_{\mathrm{PH}} \sim 3 J_{\mathrm{HH}}=7.1, \mathrm{OCH}_{2}\right), 6.34,6.54(\mathrm{~d} \times 2$, $\left.1 \mathrm{H} \times 2,3 J_{\mathrm{HH}}=1.8 \mathrm{~Hz}, \mathrm{NHC}=\mathrm{CHN}\right), 6.69,6.93\left(\mathrm{~s} \times 2,2 \mathrm{H} \times 2,3 J_{\mathrm{HH}}\right.$ not resolved, $\mathrm{NHC}=\mathrm{CHN}) \mathrm{ppm} .{ }^{13} \mathrm{C}\left\{{ }^{1} \mathrm{H}\right\} \mathrm{NMR}\left(67.9 \mathrm{MHz}, \mathrm{CDCl}_{3}\right)$ : $\delta_{\mathrm{C}}=16.8\left(\mathrm{~d},{ }^{3} J_{\mathrm{PC}}=6.1, \mathrm{CCH}_{3}\right), 33.7(2 \mathrm{C}), 34.3\left(1 \mathrm{C}, \mathrm{NCH}_{3}\right), 59.31$ $\left(\mathrm{OCH}_{2}\right), 116.6(3 \mathrm{C}), 122.4(1 \mathrm{C}), 122.5(2 \mathrm{C}, \mathrm{NCHCHN}), 170$ (br., $\mathrm{CS}$, onset of fluxionality). ${ }^{31} \mathrm{P}\left\{{ }^{1} \mathrm{H}\right\} \mathrm{NMR}\left(72.9 \mathrm{~Hz}, \mathrm{CDCl}_{3}\right): \delta_{\mathrm{P}}=156.7$ (s.br.). ${ }^{11} \mathrm{~B}\left\{{ }^{1} \mathrm{H}\right\} \mathrm{NMR}\left(86.6 \mathrm{MHz}, \mathrm{CDCl}_{3}\right): \delta_{\mathrm{B}}=14.0$ (br.). LR-FABMS (nba matrix): $m / z=646(18)[\mathrm{M}]^{+}, 618(32)[\mathrm{M}-\mathrm{CO}]^{+}, 480(3)$ $\left[\mathrm{M}-\mathrm{P}(\mathrm{OEt})_{3}\right]^{+}, 452(100)\left[\mathrm{M}-\mathrm{CO}-\mathrm{P}(\mathrm{OEt})_{3}\right]^{+}$. Anal. Found; C, 34.12; $\mathrm{H}, 4.93 ; \mathrm{N}, 12.92 \%$. Calc. for $\mathrm{C}_{19} \mathrm{H}_{30} \mathrm{BN}_{6} \mathrm{O}_{4} \mathrm{PRuS}_{3} \mathrm{C}, 34.34 ; \mathrm{H}$, 4.69; $\mathrm{N}, 13.02 \%$. Crystal data for $1 \mathrm{j}: \mathrm{C}_{19} \mathrm{H}_{30} \mathrm{BN}_{6} \mathrm{O}_{4} \mathrm{PRuS}_{3}, M_{\mathrm{w}}=$ 645.52, orthorhombic, $P b c a$ (no. 61), $a=13.3878(11), b=$ 16.5415(9), $c=25.3837(14) \AA, V=5621.3(6) \AA^{3}, Z=8, D_{\text {calcd. }}=$ $1.525 \mathrm{Mg} \mathrm{m}^{-3}, \mu(\mathrm{Cu}-\mathrm{K} \alpha)=7.445 \mathrm{~mm}^{-1}, T=293 \mathrm{~K}$, yellow prisms, 4,170 independent measured reflections $\left(R_{\text {int }}=0.0656\right), F^{2}$ refinement, $R_{1}=0.0532, w R_{2}=0.1470,3,276$ independent observed absorption-corrected reflections $\left[\left|F_{\mathrm{o}}\right|>4 \sigma\left(\left|F_{\mathrm{o}}\right|\right)\right.$, completeness to $\left.\theta_{\text {full }}\left(60.0^{\circ}\right)=100.0 \%\right], 365$ parameters. CCDC 1874178. The triethyl phosphite group in the structure of $\mathbf{1 j}$ was found to be disordered. Two orientations were identified of $c a$ 68 and 32\% occupancy, their geometries were optimised, the thermal parameters of adjacent atoms were restrained to be similar, and only the two partial occupancy phosphorus atoms and the carbon atoms of the major occupancy orientation were refined anisotropically (the rest were refined isotropically).

Synthesis of $\left.\left[\mathrm{Ru}(\mathrm{CO})\left\{\mathrm{P}(\mathrm{OPh})_{3}\right\} \mathbf{B}(\mathrm{mt})_{3}\right\}\right](\mathbf{1 k})-$ As described for $1 \mathrm{i}$ above (Method 1, 1a: $1.000 \mathrm{~g}, 1.35 \mathrm{mmol}$ ). Yield $0.937 \mathrm{~g}$ (1.19 mmol, 88\%). IR ( $\left.\mathrm{cm}^{-1}\right)$ Nujol: $1923 v_{\mathrm{CO}}, 1590 \mathrm{w}, 1185 \mathrm{~s}$, $901 \mathrm{~m}, 871 \mathrm{~m}$. IR $\left(\mathrm{cm}^{-1}\right) \mathrm{CH}_{2} \mathrm{Cl}_{2}: 1923 v_{\mathrm{CO}} .{ }^{1} \mathrm{H} \mathrm{NMR}(270 \mathrm{MHz}$, $\left.\mathrm{CDCl}_{3}\right) ; \delta=3.37\left(\mathrm{~s}, 6 \mathrm{H} ; \mathrm{NCH}_{3}\right), 3.40(\mathrm{~s}, 3 \mathrm{H}, \mathrm{NCH}=\mathrm{CHN}), 6.35$, $6.61\left(\mathrm{~d} \times 2,1 \mathrm{H} \times 2,{ }^{3} \mathrm{JHH}_{\mathrm{HH}}=1.8 \mathrm{~Hz}, \mathrm{NHC}=\mathrm{CHN}\right), 6.73,6.93(\mathrm{~d} 2,2$ $\mathrm{H} \times 2,3^{3} \mathrm{HH}$ not resolved, $\left.\mathrm{NHC}=\mathrm{CHN}\right), 7.05-7.15,7.23-7.31(\mathrm{~m} \mathrm{x}$ 2, $\left.15 \mathrm{H}, \mathrm{C}_{6} \mathrm{H}_{5}\right) \mathrm{ppm} .{ }^{13} \mathrm{C}\left\{{ }^{1} \mathrm{H}\right\} \operatorname{NMR}\left(67.9 \mathrm{MHz}, \mathrm{CDCl}_{3}\right): \delta_{\mathrm{c}}=$ $33.6(2 \mathrm{C}), 34.0\left(1 \mathrm{C}, \mathrm{NCH}_{3}\right), 116.6(3 \mathrm{C}), 121.7[\mathrm{~d}, 3 \mathrm{JPC}=4.3$, $\left.\mathrm{C}^{2,6}\left(\mathrm{C}_{6} \mathrm{H}_{5}\right)\right], 122.5(2 \mathrm{C}), 122.7(1 \mathrm{C}, \mathrm{NCHCHN}), 123.6\left[\mathrm{C}^{4}\left(\mathrm{C}_{6} \mathrm{H}_{5}\right)\right]$, $129.2\left[\mathrm{C}^{3,5}\left(\mathrm{C}_{6} \mathrm{H}_{5}\right)\right], 152.4\left[\mathrm{~d},{ }^{2} \mathrm{JPC}_{\mathrm{PC}}=5.4, \mathrm{C}^{1}\left(\mathrm{C}_{6} \mathrm{H}_{5}\right)\right], 170.2,170.5$ (CS). ${ }^{31} \mathrm{P}\left\{{ }^{1} \mathrm{H}\right\} \operatorname{NMR}\left(72.9 \mathrm{~Hz}, \mathrm{CDCl}_{3}\right): \delta_{\mathrm{P}}=136.5$ (s.br.). ${ }^{11} \mathrm{~B}\left\{{ }^{1} \mathrm{H}\right\}$ NMR (86.6 MHz, $\mathrm{CDCl}_{3}$ ): $\delta_{\mathrm{B}}=13.0$ (br.). LR-FAB-MS (nba matrix): $\mathrm{m} / \mathrm{z}=790(71)[\mathrm{M}]^{+}, 762(26)[\mathrm{M}-\mathrm{CO}]^{+}, 452(70)\left[\mathrm{M}-\mathrm{CO}-\mathrm{P}(\mathrm{OPh})_{3}\right]^{+}$. Anal. Found; C, 47.01; H, 3.94; N, 10.92\%. Calcd. for $\mathrm{C}_{31} \mathrm{H}_{30} \mathrm{BN}_{6} \mathrm{O}_{4} \mathrm{PRuS}_{3:} \mathrm{C}, 47.14 ; \mathrm{H}, 3.83 ; \mathrm{N}, 10.65 \%$.

Crystals of a dichloromethane solvate $1 \mathbf{k} .2 \mathrm{CH}_{2} \mathrm{Cl}_{2}$ suitable for crystallographic analysis were obtained from slow evaporation of a concentrated solution in dichloromethane/hexane. Crystal data for $\mathbf{1 k} \cdot 2 \mathrm{CH}_{2} \mathrm{Cl}_{2}$ : $\mathrm{C}_{31} \mathrm{H}_{30} \mathrm{BN}_{6} \mathrm{O}_{4} \mathrm{PRuS}_{3} \cdot 2\left(\mathrm{CH}_{2} \mathrm{Cl}_{2}\right), M_{\mathrm{w}}=959.49$, triclinic, $P-1$ (no. 2), $a=11.8771(4), b=12.3847(4), c=16.6567(5) \AA, \alpha=93.569(2)$, $\beta=108.863(3), \gamma=114.826(2)^{\circ}, V=2047.58(12) \AA^{3}, Z=2, D_{\text {calcd. }}$. $=1.556 \mathrm{Mg} \mathrm{m}^{-3}, \mu(\mathrm{Cu}-\mathrm{K} \alpha)=7.671 \mathrm{~mm}^{-1}, T=293 \mathrm{~K}$, pale yellow platy needles, 5,612 independent measured reflections $\left(R_{\text {int }}=\right.$ 0.0528), $F^{2}$ refinement, $R_{1}=0.0501, w R_{2}=0.1345,4,828$ independent observed absorption-corrected reflections $\left[\left|F_{\mathrm{o}}\right|>\right.$ $4 \sigma\left(\left|F_{\mathrm{o}}\right|\right)$, completeness to $\left.\theta_{\text {full }}\left(60.0^{\circ}\right)=92.3 \%\right], 504$ parameters. CCDC 1874179. The triphenylphosphite group in the structure of $\mathbf{1 k}$ was found to be disordered. Two orientations were identified of $c a .79$ and $21 \%$ occupancy, their geometries were optimized, the thermal parameters of adjacent atoms were restrained to be similar, and only the two partial occupancy phosphorus atoms and the carbon atoms of the major occupancy orientation were refined anisotropically (the rest were refined isotropically).

Synthesis of $\operatorname{mer}-\left[\mathrm{Ru}(\mathrm{CH}=\mathrm{CHPh}) \mathrm{Cl}(\mathrm{CO})\left(\mathrm{PMe}_{2} \mathrm{Ph}\right)_{3}\right](3)-\mathrm{A}$ mixture of $\left[\mathrm{Ru}(\mathrm{CH}=\mathrm{CHPh}) \mathrm{Cl}(\mathrm{CO})\left(\mathrm{PPh}_{3}\right)_{2}\right](1.00 \mathrm{~g}, 1.30 \mathrm{mmol})$ and three equivalents of dimethylphenylphosphine $(0.54 \mathrm{~mL}, 0.52 \mathrm{~g}$, $3.80 \mathrm{mmol}$ ) was stirred in $\mathrm{CH}_{2} \mathrm{Cl}_{2}(50 \mathrm{~mL})$ for 1 hour. The solvent volume was reduced under reduced pressure and ethanol (20 $\mathrm{mL}$ ) added to precipitate the white crystalline product. The precipitate was filtered off and washed with ethanol $(20 \mathrm{~mL})$ and hexane $(10 \mathrm{~mL})$. Yield $=0.68 \mathrm{~g}(79 \%) . \mathrm{IR}\left(\mathrm{cm}^{-1}\right)$ Nujol: 1919 $v_{\text {CO. }} \mathrm{CH}_{2} \mathrm{Cl}_{2}: 1918 v_{\text {CO }}{ }^{1} \mathrm{H}$ NMR $\left(300.7 \mathrm{MHz}, \mathrm{CDCl}_{3}\right): \delta_{\mathrm{H}}=1.09$ (d, ${ }^{2} J_{\mathrm{PH}}=7.2,6 \mathrm{H}$, cis- $\left.\mathrm{PMe} \mathrm{e}_{2} \mathrm{Ph}\right), 1.48\left(\mathrm{t}^{\mathrm{v}}, J_{\mathrm{PH}}=6.4,6 \mathrm{H}\right.$, trans $\left.-\mathrm{PMe}_{2}\right)$, $1.62\left(\mathrm{tv}, 6 \mathrm{H}, J_{\mathrm{PH}}=4.92 \mathrm{~Hz}\right.$, trans-PMe $\left.\mathrm{PM}_{2}\right), 6.70\left(\mathrm{dd}, 1 \mathrm{H}, \mathrm{CH}_{\beta} \mathrm{Ph}\right.$, not resolved), 8.35 (ddt, $\left.1 \mathrm{H}, \mathrm{RuCH}_{\alpha}\right), 7.08-7.49\left(\mathrm{~m}, 20 \mathrm{H}, \mathrm{C}_{6} \mathrm{H}_{5}\right)$ ppm. ${ }^{13} \mathrm{C}\left\{{ }^{1} \mathrm{H}\right\} \mathrm{NMR}\left(75.4 \mathrm{MHz}, \mathrm{CDCl}_{3}\right): \delta_{\mathrm{C}}=203.9$ (dt, not resolved, RuCO), $163.7\left[\mathrm{C}^{1}\left(\mathrm{C}_{6} \mathrm{H}_{5}\right)\right], 140.0\left[\mathrm{C}^{2,6}\left(\mathrm{C}_{6} \mathrm{H}_{5}\right)\right], 128.7$ [C $\left.\mathrm{C}^{3,5}\left(\mathrm{C}_{6} \mathrm{H}_{5}\right)\right], 124.4\left[\mathrm{C}^{4}\left(\mathrm{C}_{6} \mathrm{H}_{5}\right)\right], 14.38\left(\mathrm{PCH}_{3}\right) \mathrm{ppm} .{ }^{31} \mathrm{P}\left\{{ }^{1} \mathrm{H}\right\} \mathrm{NMR}$ $\left(121.4 \mathrm{MHz}, \mathrm{CDCl}_{3}\right): \delta_{\mathrm{P}}=-8.80\left(\mathrm{t},{ }^{2} \mathrm{JP}_{\mathrm{PP}}=23.1,1 \mathrm{P}\right.$, cis- $\left.\mathrm{PMe} \mathrm{PMh}_{2} \mathrm{Ph}\right),-$ $1.17\left[\mathrm{~d},{ }^{2} \mathrm{JPP}_{\mathrm{PP}}=23.1 \mathrm{~Hz}, 2 \mathrm{P}\right.$, trans- $\left.\left(\mathrm{PMe} \mathrm{P}_{2} \mathrm{Ph}\right)_{2}\right] \mathrm{ppm}$. FAB-MS $\mathrm{m} / \mathrm{z}$ (\%): 681(10) [M] ${ }^{+}, 579(40) \quad[\mathrm{M}-\mathrm{HCCHPh}]^{+}, \quad 544(35) \quad[\mathrm{M}-\mathrm{Cl}-$ $\mathrm{HCCHPh}]^{+}, \quad 516(55) \quad[\mathrm{M}-\mathrm{CO}-\mathrm{Cl}-\mathrm{HCCHPh}]^{+}, \quad 377(100)$ $\left[\mathrm{Ru}\left(\mathrm{PMe}_{2} \mathrm{Ph}\right)_{2}\right]^{+}$. Anal. Found: C, 58.37; H, 6.02\%. Calcd. for 
$\mathrm{C}_{33} \mathrm{H}_{40} \mathrm{ClOP}_{3} \mathrm{Ru}$ : C, 58.09; $\mathrm{H}, 5.91 \%$. Single crystals suitable for $X$ ray crystallography were obtained by layering pentane upon a $\mathrm{CH}_{2} \mathrm{Cl}_{2}$ solution of the complex. Crystal data: $\mathrm{C}_{33} \mathrm{H}_{40} \mathrm{ClOP}_{3} \mathrm{Ru} ; \mathrm{Mr}_{\mathrm{r}}$ $=682.127$, monoclinic, $P 2_{1} / c, a=15.3727(2), b=12.4583(2), c=$ 17.6126 (3) $\AA, \beta=105.0989(7)^{\circ}, V=3256.68(9) \AA^{3}, Z=4 ; D_{\text {calcd. }}$ $=1.391 \mathrm{Mgm}^{-3}, \mu(\mathrm{Mo}-\mathrm{K} \alpha)=0.74 \mathrm{~mm}^{-1}, T=200(2) \mathrm{K}$, yellow prism $0.26 \times 0.16 \times 0.14 \mathrm{~mm}, 7,457$ independent measured reflections, $F$ refinement, $R_{1}=0.031, w R_{2}=0.038,4,016$ independent observed absorption corrected reflections $(I>$ $\left.3 \sigma(I), 2 \theta \leq 55^{\circ}\right], 353$ parameters.

Synthesis of $\left[\mathrm{RuCl}(\mathrm{Ph})(\mathrm{CO})\left(\mathrm{PC}_{3}\right)_{2}\right]$ (4). A mixture of $\left[\mathrm{RuCl}(\mathrm{Ph})(\mathrm{Cl})(\mathrm{CO})\left(\mathrm{PPh}_{3}\right)_{2}\right](3.00 \mathrm{~g}, 3.92 \mathrm{mmol})$ and $\mathrm{PCy}_{3}(3.37 \mathrm{~g}$, $12.0 \mathrm{mmol})$ was dissolved THF $(40 \mathrm{~mL})$ and heated under reflux in a $\mathrm{N}_{2}$ atmosphere for 4 hours. The solution was allowed to cool to room temperature and then diluted with ethanol $(40 \mathrm{~mL})$ and concentrated to a minimum under reduced pressure to provide a red microcrystalline precipitate which was isolated by filtration. The product was washed with ethanol $(2 \times 20 \mathrm{~mL})$, dried in vacuo and stored under an oxygen- and moisture-free atmosphere. Yield $=2.52 \mathrm{~g}(3.13 \mathrm{mmol}, 80 \%) . \mathrm{IR}\left(\mathrm{cm}^{-1}\right)$ Nujol: $1897 v_{\mathrm{CO}} . \mathrm{CH}_{2} \mathrm{Cl}_{2}: 1901 v_{\mathrm{CO}}{ }^{1} \mathrm{H} \mathrm{NMR}\left(300.7 \mathrm{MHz}, \mathrm{CDCl}_{3}\right): \delta_{\mathrm{H}}=$ $1.16-1.72\left(\mathrm{~m} . \mathrm{br}, 66 \mathrm{H}, \mathrm{C}_{6} \mathrm{H}_{11}\right), 6.58-6.61,7.24-7.68(\mathrm{~m}, 5 \mathrm{H}$, $\left.\mathrm{C}_{6} \mathrm{H}_{5}\right) \mathrm{ppm} .{ }^{31} \mathrm{P}\left\{{ }^{1} \mathrm{H}\right\} \mathrm{NMR}\left(121.4 \mathrm{MHz}, \mathrm{CDCl}_{3}\right): \delta_{\mathrm{P}}=24.8$. FAB-MS: $\mathrm{m} / \mathrm{z}(\%)$ 805.2(10)[M] ${ }^{+}, 767.1(100)[\mathrm{M}-\mathrm{Cl}]^{+}$. Anal. Found: C, 63.91; $\mathrm{H}, 9.14 \%$. Calcd. for $\mathrm{C}_{43} \mathrm{H}_{71} \mathrm{ClOP}_{2} \mathrm{Ru}$ : $\mathrm{C}, 64.36 ; \mathrm{H}, 8.92 \%$. This complex with comparable spectroscopic data, has previously been obtained via the adventitious hydrolysis of Grubbs' catalyst $\left[\mathrm{Ru}(=\mathrm{CHPh}) \mathrm{Cl}_{2}\left(\mathrm{PCy}_{3}\right)_{2}\right] \cdot{ }^{19}$

Synthesis of $\left[\mathrm{Ru}(\mathrm{CH}=\mathrm{CHPh}) \mathrm{Cl}(\mathrm{CO})\left\{\mathrm{P}(\mathrm{OMe})_{3}\right\}_{3}\right](5)-\mathrm{A}$ mixture of $\left[\mathrm{Ru}(\mathrm{CH}=\mathrm{CHPh}) \mathrm{Cl}(\mathrm{CO})\left(\mathrm{PPh}_{3}\right)_{2}\right](0.55 \mathrm{~g}, 0.60 \mathrm{mmol})$ and three equivalents of $\mathrm{P}(\mathrm{OMe})_{3}(0.21 \mathrm{~mL}, 1.8 \mathrm{mmol})$ was heated under reflux in hexane $(50 \mathrm{~mL})$ for 16 hours during which time the colour faded from red to colourless. The solution was allowed to cool and the solvent removed in vacuo. The white product was recrystallised from $\mathrm{CH}_{2} \mathrm{Cl}_{2}(10 \mathrm{~mL})$ and petroleum spirit $(10 \mathrm{~mL})$. This is a very soluble compound, which compromises the isolated yield though the reaction is spectroscopically quantitative. Yield $=0.23 \mathrm{~g}(59 \%) . \mathrm{IR}\left(\mathrm{cm}^{-1}\right)$ Nujol: $1969 v_{\mathrm{CO}} . \mathrm{CH}_{2} \mathrm{Cl}_{2}$ : $1969 v_{\mathrm{CO}} \cdot{ }^{31} \mathrm{P}\left\{{ }^{1} \mathrm{H}\right\} \mathrm{NMR}(121.4 \mathrm{MHz}$, $\left.\mathrm{C}_{6} \mathrm{D}_{6}\right): \delta_{\mathrm{P}}=128.9\left[\mathrm{~d},{ }^{2} \mathrm{~J}_{\mathrm{AB}}=42.3,2 \mathrm{P}\right.$, trans- $\left.\mathrm{P}(\mathrm{OMe})_{3}\right], 142.4\left[\mathrm{t},{ }^{2} \mathrm{~J}_{\mathrm{AB}}\right.$ $=43.0 \mathrm{~Hz}, 1 \mathrm{P}$, cis-P(OMe $\left.)_{3}\right]$ ppm. FAB-MS: $m / z$ (\%): $639.9(3)[\mathrm{M}]^{+}, \quad 607.0(4)[\mathrm{M}-\mathrm{Cl}]^{+}, \quad 583.7(20)[\mathrm{M}-\mathrm{CO}-\mathrm{Cl}]^{+}$. Anal. Found $\mathrm{C}, 33.81 ; \mathrm{H}, 5.18 \%$. Calc. for $\mathrm{C}_{18} \mathrm{H}_{34} \mathrm{O}_{4} \mathrm{ClP}_{3} \mathrm{Ru}$ : C, 33.78; $\mathrm{H}$, $5.32 \%$.

Synthesis of $\left[\mathrm{Ru}(\mathrm{CH}=\mathrm{CHPh}) \mathrm{Cl}(\mathrm{CO})\left\{\mathrm{P}(\mathrm{OMe})_{3}\right\}\left(\mathrm{PPh}_{3}\right)_{2}\right]$ (6) To a solution of $\left[\mathrm{Ru}(\mathrm{CH}=\mathrm{CHPh}) \mathrm{Cl}(\mathrm{CO})\left(\mathrm{PPh}_{3}\right)_{2}\right](0.55 \mathrm{~g}, 0.60$ $\mathrm{mmol})$ in $\mathrm{CH}_{2} \mathrm{Cl}_{2}(60 \mathrm{~mL})$ was added $\mathrm{P}(\mathrm{OMe})_{3}\left(0.25 \mathrm{~cm}^{3}, 1.8\right.$ $\mathrm{mmol})$. The mixture was stirred at room temperature and an instant colour change from red to light yellow was observed, however the reaction was left to stir for further two hours. The $\mathrm{CH}_{2} \mathrm{Cl}_{2}$ solvent was reduced to a minimum (ca $10 \mathrm{~mL}$ ) and ethanol $(20 \mathrm{~mL})$ added and the total volume further reduced slowly under reduced pressure to provide an off-white

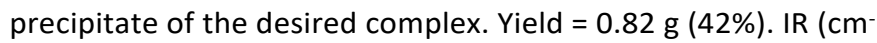
1) Nujol: $1955 v_{\text {co. }}{ }^{1} \mathrm{H}$ NMR $\left(300.7 \mathrm{MHz}, \mathrm{C}_{6} \mathrm{D}_{6}\right): \delta_{\mathrm{H}}=3.32(\mathrm{~d}, 9 \mathrm{H}$, $\left.3 J_{\mathrm{PH}}=10.1, \mathrm{POCH}_{3}\right), 5.70$ (dd, $\left.1 \mathrm{H}, \mathrm{CH}_{\beta} \mathrm{Ph}\right), 8.35$ (m=ddt, not resolved, $\left.1 \mathrm{H}, \mathrm{RuCH}_{\alpha}\right), 7.24-7.26,7.74-7.80\left(\mathrm{~m}, 35 \mathrm{H}, \mathrm{C}_{6} \mathrm{H}_{5}\right) \mathrm{ppm}$. ${ }^{31} \mathrm{P}\left\{{ }^{1} \mathrm{H}\right\} \operatorname{NMR}\left(121.4 \mathrm{MHz}, \mathrm{C}_{6} \mathrm{D}_{6}\right) ; \delta_{\mathrm{P}}=127.7\left[\mathrm{t},{ }^{2} J_{\mathrm{PP}}=43.6\right.$,
$\left.\mathrm{P}(\mathrm{OMe})_{3}\right], 22.6\left[\mathrm{~d},{ }^{2} \mathrm{JPP}_{\mathrm{PP}}=43.6 \mathrm{~Hz}, 2 \mathrm{P}\right.$, trans $\left.-\mathrm{PPh}_{3}\right] \mathrm{ppm}$. Anal. Found: C, 63.21; $\mathrm{H}, 5.36 \%$. Calcd. for $\mathrm{C}_{48} \mathrm{H}_{46} \mathrm{ClO}_{4} \mathrm{P}_{3} \mathrm{Ru}$ : C, 62.90; H, 5.06\%.

\section{Acknowledgements}

This work was supported by the Australian Research Council (DP170102695). The authors declare no conflicts of interest.

\section{Notes and references}

1 (a) H. Braunschweig and R. D. Dewhurst, Dalton Trans., 2011, 40, 549 - 558. (b) A. Amgoune and D. Bourissou, Chem. Commun., 2011, 47, 859 - 871. (c) G. Bouhadir and D. Bourissou, Chem. Soc. Rev., 2016, 45, 1065 - 1079. (d) G. R. Owen, Chem. Soc. Rev., 2012, 41, $3535-3546$.

2 A. Haarland, Angew. Chem., Int. Ed., 1989, 28, $922-1007$.

3 Group 8 (a) J. S. Figueroa, J. G. Melnick and G. Parkin, Inorg. Chem., 2006, 45, 7056 - 7058. (b) A. F. Hill, G. R. Owen, A. J. P. White and D. J. Williams, Angew. Chem., Int. Ed., 1999, 38, 2759 - 2761. (c) I. R. Crossley, M. R. St.-J. Foreman, A. F. Hill, G. R. Owen, A. J. P. White, D. J. Williams and A. C. Willis, Organometallics, 2008, 27, 381 - 386. (d) M. R. St.-J. Foreman, A. F. Hill, G. R. Owen, A. J. P. White and D. J. Williams, Organometallics, 2003, 22, 4446-4450. (e) H. Zhu, Q. Ma, A.Q. Jia, Q. Chen, W.-H. Leung and Q.-F. Zhang, Inorg. Chim. Acta, 2013, 405, 427 - 436. (f) M. R. St.-J. Foreman, A. F. Hill, A. J. P. White and D. J. Williams, Organometallics, 2004, 23, $913-916$.

4 Group 9: (a) D. J. Mihalcik, J. L. White, J. M. Tanski, L. N. Zakharov, G. P. A. Yap, C. D. Incarvito, A. L. Rhenigold and D. Rabinovich, Dalton Trans., 2004, 1626 - 1634. (b) I. R. Crossley, A. F. Hill and A. C. Willis, Organometallics, 2005, 24 1062 - 1064. (c) I. R. Crossley, M. R. St.-J. Foreman, A. F. Hill, A. J. P. White and D. J. Williams, Chem. Commun., 2005, $221-$ 223. (d) I. R. Crossley, A. F. Hill, A. C. Willis, Organometallics, 2005, 24, 1062 - 1064. (e) I. R. Crossley, A. F. Hill and A. C. Willis, Organometallics, 2007, 26, 3891 - 3895. (f) I. R. Crossley, A. F. Hill, E. R. Humphrey and A. C. Willis, Organometallics, 2005, 24, 4083 - 4086. (g) I. R. Crossley, A. F. Hill and A. C. Willis, Organometallics, 2007, 26, 3891 3895. (h) I. R. Crossley, A. F. Hill and A. C. Willis, Organometallics, 2010, 29, 326 - 336. (i) V. K. Landry, J. G. Melnick, D. Buccella, K. Pang, J. C. Ulichny and G. Parkin, Inorg. Chem., 2006, 45, 2588 - 2597. (j) R. J. Blagg, J. P. H. Charmant, N. G. Connelly, M. F. Haddow and A. Guy Orpen, Chem. Commun., 2006, 2350 - 2352. (k) R. J. Blagg, C. J. Adams, J. P. H. Charmant, N. G. Connelly, M. F. Haddow, A. Hamilton, J. Knight, A. G. Orpen and B. M. Ridgeway, Dalton Trans., 2009, 8724 -8736. (I) M. J. López-Gómez, N. G. Orpen, M. F. Haddow, A. Hamilton and A. G. Orpen, Dalton Trans., 2010, 39, 5221 - 5230. (m) R. J. Blagg, N. G. Connelly, M. F. Haddow, A. Hamilton, M. Lusi, A. G. Orpen and B. M. Ridgeway, Dalton Trans., 2010, 39, 11616-11627. (n) M. J. López-Gómez, N. G. Connelly, M. F. Haddow, A. Hamilton, M. Lusi, U. Baisch and A. G. Orpen, Dalton Trans., 2011, 40, 4647 - 4659. (o) N. Tsoureas, M. F. Haddow, A. Hamilton and G. R. Owen, Chem. Commun., 2009, 2538 - 2540. (p) N. Tsoureas, T. Bevis, C. P. Butts, A. Hamilton and G. R. Owen, Organometallics, 2009, 28, $5222-5232$. (q) G. R. Owen, P. H. Gould, J. P. H. Charmant, A. Hamilton and S. Saithon, Dalton Trans., 2010, 39, $392-400$. (r) N. Tsoureas, Y.-Y. Kuo, M. F. Haddow and G. R. Owen, Chem. Commun., 2011, 47, 484 - 486. (s) G. Dyson, A. Zech, B. J. Rawe, M. F. Haddow, A. Hamilton and G. R. Owen, Organometallics, 2011, 30, $5844-5850$. (t) N. Tsoureas, A. Hamilton, M. F. Haddow, J. N. Harvey, A. G. Orpen and G. R. Owen, Organometallics, 2013, 32, 2840 - 2856. (u) S. Holler, 
M. Tüchler, A. M. Knaus, F. Belaj, N. C. Mösch-Zanetti, Polyhedron, 2017, 125, 122 - 129. (v) G . Nuss, G. Saischek, B N. Harum, M. Volpe, K. Gatterer, F. Belaj and N. C. MöschZanetti, Inorg. Chem., 2011, 50, 1991 - 2001. (w) S. Holler, M. Tüchler, M. C. Roschger, F. Belaj, L. F. Veiros, K. Kirchner and N. C. Mösch-Zanetti, Inorg. Chem., 2017, 56, 12670 - 12673. (x) R. S. Anju, D. K. Roy, B. Mondal, K. Yuvaraj, C. Arivazhagan, K. Saha, B. Varghese and S. Ghosh, Angew. Chem., Int. Ed. 2014, 53, 2873 - 2877. (y) D. K. Roy, B. Mondal, R. S. Anju and S. Ghosh, Chem. Eur. J., 2015, 21, 3640 - 3648. (z) D. K. Roy, A. De, S. Panda, B. Varghese and S. Ghosh, Chem. Eur. J., 2015, 21, $13732-13738$.

5 (a) I. R. Crossley and A. F. Hill, Organometallics, 2004, 23, 5656 - 5658. (b) I. R. Crossley, A. F. Hill and A. C. Willis, Organometallics, 2008, 27, 312 - 315. (c) I. R. Crossley and A. F. Hill, Dalton Trans., 2008, 201 - 203. (d) S. Senda, Y Ohki, T. Hirayama, D. Toda, J.-L. Chen, T. Matsumoto, H. Kawaguchi and K. Tatsumi, Inorg. Chem., 2006, 24, 9914 9925. (e) K. Pang, J. M. Tanski and G. Parkin, Chem. Commun., 2008, 1008 - 1010. (f) K. Pang, S. M. Quan and G. Parkin, Chem. Commun., 2006, 5015 - 5017. (g) G. R. Owen, P. H. Gould, A. Hamilton and N. Tsoureas, Dalton Trans., 2010, 39, 49-52. (h) A. Zech, M. F. Haddow, H. Othman and G. R. Owen, Organometallics, 2012, 31, 6753 - 6760. (i) A. Neshat, H. R. Shahsavari, P. Mestrorilli, S. Todisco, M. G. Haghighi and B. Notash, Inorg. Chem., 2018, 57, $1398-1407$.

6 (a) S. Holler, M. Tüchler, F. Belaj, L. F. Veiros, K. Kirchner and N. Mösch-Zanetti, Inorg. Chem., 2016, 55, 4980 - 4991. (b) G. Nuss, G. Saischek, B. N. Harum, M. Volpe, F. Belaj and N. C. Mösch-Zanetti, Inorg. Chem., 2011, 50, 12632 - 12640.

7 Hereafter, mt implicitly refers to $\mathrm{N}$-methyl-2mercaptoimidazolyl and $\mathrm{mt}^{\mathrm{R}}$ refers to the various derivatives $N$-R-2-mercaptoimidazolyl with varying $N$-substituents $\mathrm{R}$.

8 (a) S. Bontemps, H. Gornitzka, G. Bouhadir, K. Miqueu and D. Bourissou, Angew. Chem., Int. Ed., 2006, 45, 1611 - 1614. (b) S. Bontemps, G. Bouhadir, P. W. Dyer, K. Miqueu, D. Bourissou, Inorg. Chem., 2007, 46, 5149 - 5151 (c) S. Bontemps, M. Sircoglou, G. Bouhadir, H. Puschmann, J. A. K. Howard, P. W. Dyer, K. Miqueu and D. Bourissou, Chem.-Eur. J., 2008, 14, 731- 740 .

9 (a) W.-C. Shih, W. Gu, M. C. Macinnis, D. E. Herbert and O. V. Ozerov, Organometallics, 2017, 36, 1718 - 1726. (b) T. J. De Castillo, N. B. Thompson, D. L. M. Suess, G. Ung and J. C. Peters, Inorg. Chem., 2015, 54, 9256 - 9262. (c) D. L. M.Suess, C. Tsay and J. C. Peters, J. Am. Chem. Soc., 2012, 134, 14158 - 14164. (d) H. Kameo, Y. Hashimoto and H. Nakazawa, Organometallics, 2012, 31, $4251-4258$. (e) H. Kameo and H. Nakazawa, Organometallics, 2012, 31, 7476 - 7478. (f) H. Kameo, Y. Hashimoto, H. Nakazawa, Organometallics, 2012 31, 3155 - 3162. (g) C. M. Conifer, D. J. Law, G. J. Sunley, A. J. P. White and G. J. P. Britovsek, Organometallics, 2011, 30, 4060 - 4066. (h) S. R. Oakley, K. D. Parker, D. J. H. Emslie, I. Vargas-Baca, C. M. Robertson, L. E. Harrington and J. F. Britten, Organometallics, 2006, 25, 5835 - 5838.

10 R. Malacea, F. Chahdoura, M. Devillard, N. Saffon, M. Gomez and D. Bourissou, Adv. Synth. Catal., 2013, 355, $2274-2284$ (b) S. Bontemps, G. Bouhadir, W. Gu, M. Mercy, C.-H. Chen, B. M. Foxman, L. Maron, O. V. Ozerov, D. Bourissou, Angew. Chem. Int. Ed., 2008, 47, 1481 - 1484. (c) M. Sircoglou, S. Bontemps, G. Bouhadir, N. Saffon, K. Miqueu, W. Gu, M. Mercy, C.-H. Chen, B. M. Foxman, L. Maron, O. V. Ozerov, D. Bourissou, J. Am. Chem. Soc., 2008, 130, 16729 - 16738. (d) W. H. Harman and J. C. Peters, J. Am. Chem. Soc., 2012, 134 5080 - 5082. (e) W. H. Harman, T.-P. Lin and J. C. Peters, Angew. Chem., Int. Ed., 2014, 53, 1081-1086. (f) T. Schindler, M. Lux, M. Peters, L. T. Scharf, H. Osseili, L. Maron and M. E. Tauchert, Organometallics, 2015, 34, 1978-1984. (g) S. Xu, Y. Zhang, B. Li and S.-Y. Liu, J. Am. Chem. Soc., 2016, 138, 1456614569. (h) D. Schuhknecht, F. Ritter, M. E. Tauchert, Chem.
Commun., 2016, 52, 11823 - 11826. (i) P. Steinhoff, M. E. Tauchert, Beilstein J. Org. Chem., 2016, 12, 1573 - 1576.

11 (a) M. Sircoglou, S. Bontemps, M. Mercy, K. Miqueu, S. Ladeira, N. Saffon, L. Maron, G. Bouhadir and D. Bourissou, Inorg. Chem., 2010, 49, 3983 - 3990. (b) M. Sircoglou, S. Bontemps, M. Mercy, N. Saffon, M. Takahashi, G. Bouhadir, L. Maron and D. Bourissou, Angew. Chem., Int. Ed., 2007, 46, 8583-8586. (c) M.-E. Moret, L. Zhang and J. C. Peters, J. Am. Chem. Soc., 2013, 135, 3792-3792. (d) F. Inagaki, K. Nakazawa, K. Maeda, T. Koseki and C. Mukai, Organometallics, 2017, 36, 3005 - 3008. (e) F. Inagaki, C. Matsumoto, Y. Okada, N. Maruyama and C. Mukai, Angew. Chem., Int. Ed., 2015, 54, 818-822.

12 (a) M. M. Deegan and J. C. Peters, Chem. Sci., 2018, 9, $6264-$ 6270. (b) M. A. Nesbit, D. L. M. Suess and J. C. Peters, J. Am. Chem. Soc., 2017, 139, 15312 - 15315. (c) M. M. Deegan and J. C. Peters, J. Am. Chem. Soc., 2017, 139, 2561 - 2564. (d) N. B. Thompson, M. T. Green, M. J. Chalkley and J. C. Peters, Angew. Chem., Int. Ed., 2016, 55, 11995 - 11998. (e) M. A. Nesbit, D. L. M. Suess and J. C. Peters, Organometallics, 2015, 34, 4741 - 4752. (f) D. L. M. Suess and J. C. Peters, J. Am. Chem. Soc., 2013, 135, $12580-12583$. (g) J. S. Anderson, M.E. Moret and J. C. Peters, J. Am. Chem. Soc., 2013, 135, 534 - 537. (h) M.-E. Moret and J. C. Peters, Angew. Chem., Int. Ed., 2011, 50, 2063 - 2067. (i) D. L. M. Suess and J. C. Peters, J. Am. Chem. Soc., 2013, 135, 4938. (j) H. Fong, M.-E. Moret, Y. Lee and J. C. Peters, Organometallics, 2013, 32, 3053 - 3062. (k) T. J. Del Castillo, N. B. Thompson and J. C. Peters, J. Am. Chem. Soc., 2016, 138, 5341-5350. (I) M.-E. Moret and J. C. Peters, J. Am. Chem. Soc., 2011, 133, 18118-18121.

13 Herein we consider the borane cage in metallaboratranes to be neutral $\mathrm{BR}_{3}$ units such that complexes such as $\mathbf{1}$ are arbitrarily deemed to be zerovalent. For further discussions on oxidation state and $\mathrm{d}^{\mathrm{n}}$ assignments for metallaboratranes see (a) A. F. Hill, Organometallics, 2006, 25, 4741 - 4743. (b) G. Parkin, Organometallics, 2006, 25, $4744-4747$.

14 M. L. H. Green, J. Organomet. Chem., 1995, 500, 127 - 148.

15 Using the $(M \rightarrow B)^{n}$ electronic book-keeping descriptor ${ }^{13 a}$ for which $\mathrm{n}$ is the number of metal valence electrons including the electron pair involved in the $\mathrm{M} \rightarrow \mathrm{B}$ bond, the complexes described herein are all RuL ${ }_{5} Z^{14}$ i.e., $(R u \rightarrow B)^{8}$ species.

16 (a) R. J. Abernethy, A. F. Hill, N. Tshabang, A. C. Willis and R. D. Young, Organometallics, 2009, 28, 488 - 492. (b) M. R. St.J. Foreman, C. Ma, A. F. Hill, N. E. Otten, M. Sharma, N. Tshabang and J. S. Ward, Dalton Trans., 2017, 46, 14957 14972.

17 J. E. Probitts, D. R. Saunders, M. H. Stone and R. J. Mawby, J. Chem. Soc., Dalton Trans., 1986, $1167-1173$

18 M. R. Torres, A. Vegas, A. Santos and J. Ros, J. Organomet. Chem., 1986, 309, $169-177$.

19 M. B. Dinger and J. C. Mol, Organometallics, 2003, 22, 1089 $-1095$.

20 C. A. Tolman, Chem. Rev., 1977, 77, 313 -348.

21 P. P. M. de Lange, H.-W. Frühauf, M. J. A. Kraakman, M. van Wijnkoop, M. Kranenburg, A. H. J. P. Groot and K. Vrieze Organometallics, 1993, 12, $417-427$.

22 (a) M. Bigorgne, J. Organomet. Chem., 1963, 1, 101 - 119. (b) M. Bigorgne and L. Rassat, Bull. Soc. Chim. Fr., 1963, $295-$ 303. 